\title{
Kernos
}

Revue internationale et pluridisciplinaire de religion grecque antique

$31 \mid 2018$

Varia

\section{Herodotus on Sacred Marriage and Sacred Prostitution at Babylon}

\section{Eva Anagnostou-Laoutides and Michael B. Charles}

\section{(2) OpenEdition}

\section{Journals}

Electronic version

URL: https://journals.openedition.org/kernos/2653

DOI: 10.4000/kernos.2653

ISSN: 2034-7871

\section{Publisher}

Centre international d'étude de la religion grecque antique

\section{Printed version}

Date of publication: 1 December 2018

Number of pages: 9-37

ISBN: 978-2-87562-055-2

ISSN: 0776-3824

\section{Electronic reference}

Eva Anagnostou-Laoutides and Michael B. Charles, "Herodotus on Sacred Marriage and Sacred Prostitution at Babylon", Kernos [Online], 31 | 2018, Online since 01 October 2020, connection on 08 December 2022. URL: http://journals.openedition.org/kernos/2653; DOI: https://doi.org/10.4000/ kernos. 2653

This text was automatically generated on 24 January 2021.

All rights reserved 


\title{
Herodotus on Sacred Marriage and Sacred Prostitution at Babylon
}

\author{
Eva Anagnostou-Laoutides and Michael B. Charles
}

In this article, abbreviations follow the "Liste des périodiques" in L'Année philologique. Other abbreviations are as per $\mathrm{OCD}^{3}$. Translations of ancient texts are attributed to their respective translator as they are used.

\section{Introduction}

1 The article examines two passages in Herodotus: a) his description of the ziggurat at Babylon (1.181.5-182.1-2 and 1.199), which has been often quoted as corroborating evidence for the practice of "sacred marriages" in the ancient Near East; ${ }^{1}$ and b) his description of the custom of Babylonian temple prostitution at 1.199, which locus has generally been interpreted as a claim that all Babylonian women were required to prostitute themselves once in their life for religious purposes. ${ }^{2}$ Although Herodotus' purported ethnocentrism, as advanced by earlier Herodotean scholars, has been seriously challenged in more recent scholarship, ${ }^{3}$ the aforementioned loci are still used as evidence of Herodotus' supposed inherent bias against what he allegedly imagined as the culturally inferior peoples of the East, or at the very least, his uncritical reliance on earlier Greek writers espousing such viewpoints. ${ }^{4}$ Thus, in line with recent more nuanced readings of the Histories, it is possible to argue that, with respect to the two loci of interest to us, Herodotus did not wish to criticize the Babylonians - or Near Eastern peoples in general for that matter - on an ethnic basis, but rather was trying to make a general comment about the extremes of human nature and religious superstition. Moreover, the alleged Greek bias against the Babylonians as one of the oriental peoples supposedly lacking the cultural sophistication of the Greeks seems to have been imposed on Herodotus' text by later authors writing under the Roman Empire, such as Strabo and Curtius Rufus (discussed below, p. 18-20). Their views were further privileged and propagated by modern scholars of the nineteenth and twentieth centuries, who had in mind Aristotle's explicit bias against oriental peoples, ${ }^{5}$ and who 
read Herodotus' work through a distinctly colonial lens. It is important to note that our observations are limited to the topics of "sacred marriage" and "sacred prostitution" and therefore, we do not wish to deny Herodotus' cultural bias in the Histories in general - in our view, each Herodotean narrative suspected of bias deserves to be examined in its own right.

2 The "sacred marriage" ritual, ${ }^{6}$ staged by Near Eastern kings since the time of the Sumerians as a means of establishing their rule or re-affirming divine patronage, has been often perceived as a primitive way of worshipping the divine and, accordingly, as symptomatic of the lack of sophistication of the early societies that celebrated it. ${ }^{7}$ The surviving royal hymns and inscriptions reporting the ritual refer in very explicit language to the passionate sexual affair between the king and the goddess Inanna, which was modeled on the affair of the goddess with her divine consort Dumuzi. ${ }^{8}$ In the ritual re-enactment of this affair, the king played the role of Dumuzi, and the priestess that of the goddess - hence they were allegedly expected to have actual rather than merely symbolic sexual relations during the ceremony. ${ }^{9}$ In this vein, Smith defined "sacred marriages" as "sexual relations between humans as a ritual imitation of sexual relations on the divine plane, designed to promote fertility, or symbolic representation or evocation of these sexual relations." ${ }^{10}$ Indeed, the ritual was part of the annual reestablishment of the cosmic order during the New Year Festival, for which the king was responsible. The "sacred marriage" demonstrated the king's exclusive privilege to modulate the fertility of the goddess and therefore maintain the cosmic balance. Although, by the first millennium, the king and priestess were probably replaced by cultic statues, ${ }^{11}$ the use of sexual ecstasy as a valid means of communicating with the god was never eradicated from ancient Near Eastern societies, which continued to celebrate "sacred marriages" in various forms, especially at times of crisis.

Herodotus, who related the customs of the Babylonians in the first book of the Histories, published around $425 \mathrm{BCE}$, was aware of this and described two incidents referring to "sacred marriage." However, unlike earlier attempts, such as those of Cooper and Lapinkivi, to explain the "sacred marriage" literally, ${ }^{12}$ i.e., as a symptom of humanity's attempts to communicate with the divine, we argue that the meaning of "sacred marriage" was likely metaphorical from the beginning, and that Herodotus was perfectly aware of it - as was Xenophon, who wrote one generation after Herodotus (see various passages in Oeconomicus discussed below, p. 15-17). After all, the Greeks did celebrate similar theogamia between Zeus and Hera, as well as between Dionysus and Ariadne, his Cretan bride, with these theogamia typically being enacted in some form by the priest and/or priestess of these deities. ${ }^{13}$ Since, in all probability, actual intercourse was not involved in any of the celebrations of "sacred marriage," Herodotus did not mention it as a sign of Babylonian moral decline, as later writers such as Diodorus and Strabo understood it to be; rather, he regarded the described practices as an extreme example of religious naïveté, especially on the part of those believing that divine will can be readily harnessed to attend to human hopes and desires. Nevertheless, Herodotus' alleged cultural bias against the Babylonians, promoted by later Roman historians who claim or imply that Herodotus was their source both for what they report, and their interpretation of the material, has had a longstanding influence on the way in which modern scholars have appreciated the ritual of "sacred marriage" and its potential connection to "sacred prostitution." 
In fact, as we shall see, modern scholars commonly associated Herodotus' description (1.199) of the "sacred marriage" ritual with his reference to "sacred or cultic prostitution" performed at the temple of the Assyrian goddess Mylitta. Although both descriptions fall under the customs of the Babylonians described in Book I, Herodotus himself does not encourage their fusion, which nevertheless lingers in modern scholarship. Saggs, for example, who wrote a popular treatment of Babylonian culture, argued that "the third millennium royal ritual concerning sacred marriage of a god and goddess had by the first millennium degenerated into the practice of lower grades of priestess offering themselves to strangers." ${ }^{14}$ However, a close reading of the text in question will reveal that Herodotus was not shocked by the practice of prostitution per $s e$, for the Babylonians were hardly different from the Greeks or other ancient Mediterranean or Near Eastern peoples in their approach to it. Rather, he was astounded by the presumption of respectable, freeborn wives that a goddess' favor could be sought by participating in such activities. Of course, our argument does not refute the existence of "sacred prostitution" in antiquity overall, but we are keen to cast doubt on the use of Herodotus' 1.199 as unequivocal evidence for this practice by pointing out how the Roman historians' readings of the passage have influenced our interpretation of the Greek text.

\section{Sacred Marriage}

5 Herodotus' much-quoted text on "sacred marriage" refers to a male god, here compared to Ammon Zeus, wishing to sleep with a mortal. Given that the Babylonian Marduk was identified with Zeus, it makes sense to understand the god in the text as the Babylonian Bel Marduk (Lord Marduk). ${ }^{15}$ It is worth citing the passage verbatim: ${ }^{16}$

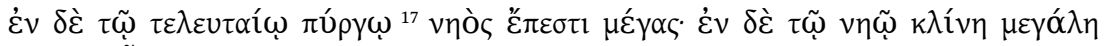

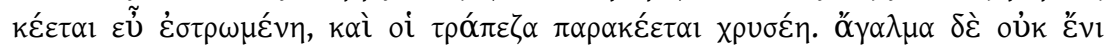

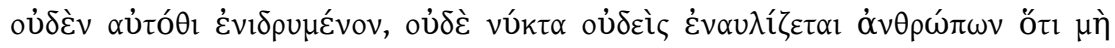

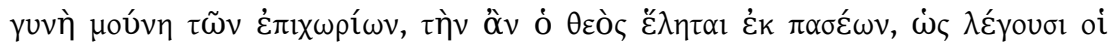

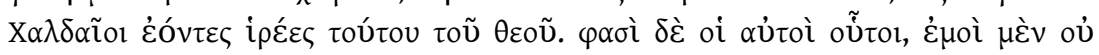

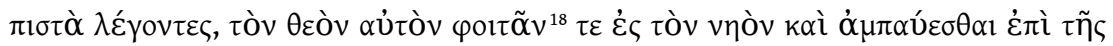

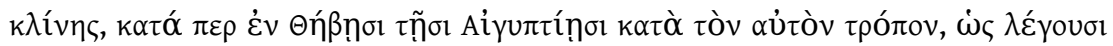

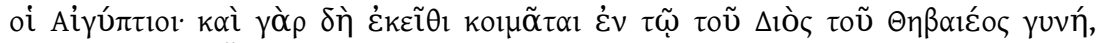

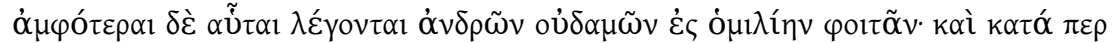

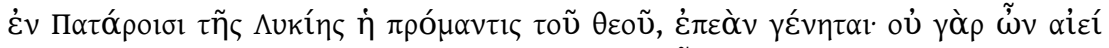

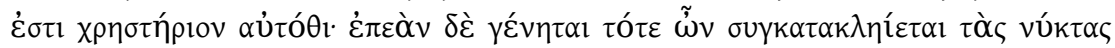

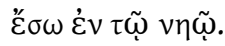

And in the last tower there is a large cell and in that cell there is a large bed, well covered, and a golden table is placed near it. And there is no image set up there nor does any human being spend the night there except only one woman of the natives of the place, whomsoever the god shall choose from all the women, as the Chaldaeans say who are the priests of this god. These same men also say, but I do not believe them, that the god himself comes often to the cell and rests upon the bed, just as it happens in the Egyptian Thebes according to the report of the Egyptians, for there also a woman sleeps in the temple of the Theban Zeus (and both these women are said to abstain from contact with men), and as happens also with the prophetess of the god in Patara in Lycia, whenever there is one, for there is not always an oracle there, but whenever there is one, then she is shut up during the nights in the temple within the cell). 
6 Herodotus concedes that the god "chooses" the woman ( $\left.{ }^{\prime} \lambda \eta \tau \alpha \mathrm{l}\right)$ and that he "rests"

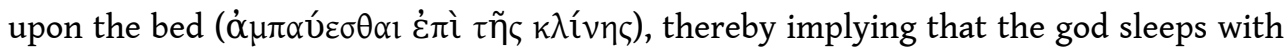
the priestess. But the text lacks the explicit vocabulary that would allow us to assume with confidence that a sexual relationship was meant to take place here, unlike the few occasions where the verb is used with clear sexual connotations. ${ }^{19}$ In fact, what the priests most probably say here, using the figurative language that servants of gods typically employed ${ }^{20}$ is that the god visits the woman and inspires her while asleep with one of his oracles. The phenomenon was apparently known, as Herodotus stresses, in Egyptian Thebes and Lycia. It could, therefore, be argued that the practice refers to cases of incubation in search of the divine will, a practice popular throughout the ancient Near East. ${ }^{21}$ In fact, it was generally believed that divine dreams could be precipitated by sleeping at the temple of the god, ${ }^{22}$ a notion familiar to the Greeks of the Hellenistic period, who similarly believed in therapeutic incubation. This was especially so in connection with the cult of Asclepius, as attested by Pausanias and Strabo. ${ }^{23}$ Diodorus also mentions this form of incubation in connection with the Egyptian Isis. ${ }^{24}$

7 In the tradition of the ancient Near East, such dreams often had a connection to legitimizing the king's rule, and were attested from the earliest times. ${ }^{25}$ For example, Gudea of Lagash (ca. 2144-2124 BCE) explained on his famous cylinder how he sought a dream from the god Ningiršu, which he then related to his mother, a dream interpreter, for further analysis. ${ }^{26} \mathrm{Often}$, the dreams resulted in requests from the gods for bigger, better temples that the king ought to build for them. From the time of Gudea to the time of Tukulti-Ninurta I (1244-1208 BCE), building temples was a sign of divine favor and a way of securing the king's immortality. ${ }^{27}$ In one case, the goddess Ištar sent a message, in the form of a dream, to the Assyrian king Aššurbanipal (685-627 BCE) through a professional dream interpreter, who was then to pass it on to the king. The dream occurs during the war against Elam, and was presumably received in the temple of the goddess. While Aššrbanipal prays, obviously awake, and indeed receives comforting words from the goddess herself, the goddess also sends a dream to a šabrû (a male dream interpreter), with specific instructions concerning what Aššurbanipal should do. Since message dreams can be used to justify political actions, Butler interprets them as "propaganda." ${ }^{28}$ For example, the dream of Gudea explains the motivation behind building a temple (Gudea Cylinder A). Having received an unsolicited dream from the god Ningiršu, Gudea, seeking further help, offers bread and water to the goddess Gatumdug. He then sets up a bed next to her statue and sleeps there, but not before praying to Gatumdug for a sign and calling on the goddess Nanše, the interpreter of dreams, to interpret it for him. All the dreams relate to the building of the temple. The Hittites had a similar practice, with the receiver of the dream being either the king himself, or a prophet or priestess. ${ }^{29}$ One might well recall the case of Nabonidus (556-539 BCE), mentioned briefly in the Histories as Labynetus, ${ }^{30}$ who interpreted a lunar eclipse on the thirteenth of the month Elul as a celestial sign that the Moon-god "desired" a priestess, understood to be the god's "mistress" (irišu enta). ${ }^{31}$

8 The question to be asked, here, is whether the ancient Greeks, including Herodotus, understood these reports to imply actual sexual activity between the god and the priestess. Herodotus' description seems to be quite close to the figurative speech found in cuneiform sources, such as the clay cylinder of Nabonidus, reportedly from Ur..$^{32}$ In addition, Herodotus does not seem to comment specifically on the nature of the 
relationship between the god and his chosen priestess, probably because he appreciated the allegorical language of the priests. ${ }^{33}$ What he doubts, though, is that any actual epiphany took place in this instance, or even whether divine epiphanies could be achieved at all by this means..$^{34}$ Hence, Herodotus' objection does not relate to the "sacred marriage" ceremony. Instead, it relates to the rite's effectiveness as a means of communicating with the divine. Such a reading is compatible with recent evaluations of Herodotus and his employment of religion as a way of explaining the downfall of powerful rulers - it is not the god who is at fault, of course, but the mortal worshippers who fail to interpret the signs correctly. ${ }^{35}$

of particular interest to us is that a number of texts accuse Nabonidus of cultic innovations that had not been demanded by the gods at all. ${ }^{36}$ Indeed, Nabonidus' religious piety had already been systematically exaggerated in the autobiography of his mother, Adad-guppi, as a way of legitimizing her son's claim to power. The god's "desire" for a priestess, who was in fact Nabonidus' daughter, should be understood in the same light, as is argued by Melville. ${ }^{37}$ Obviously, then, in the first millennium BCE, the need for "sacred marriages" as a means of communicating with the divine did not wane. Much later, Antiochus IV Epiphanes, the Seleucid king of Syria, is said to have enthusiastically celebrated a number of "sacred marriages" across his kingdom. ${ }^{38}$ Thus, Antiochus was able to pose as restorer of ancient pre-Hellenistic practices and defend his legitimacy as ruler of all the areas under his sway. When one takes into account the considerable challenges that Antiochus faced in establishing his rule, ${ }^{39}$ it is little wonder that he resorted to reviving Near Eastern rites to emphasize his legitimacy. As Pongratz-Leisten argues, "marriage between mortal king and goddess finds direct Babylonian precedents and appears to cement the Seleukid king firmly within a Semitic religious context." ${ }^{40}$

The ideology of the "sacred marriage," as it survived in the first millennium BCE, can also explain the preoccupation of kings with building projects, and particularly the notion of constructing magnificent royal gardens. The "sacred marriage" typically takes place in the "holy garden" of the goddess, which the king is required to tend as its "gardener." "Thus, in Sumerian "sacred marriage" hymns, the goddess sings of her vulva, her "uncultivated land" and asks "who will plough it?" Dumuzi, as expected, offers himself up for the task. ${ }^{42}$ Furthermore, the importance of gardens in Near Eastern palace architecture is also reflected in the tale of Inanna and the Huluppu Tree where the legendary hero-king Gilgamesh poses as the gardener of the goddess; ${ }^{43}$ in his steps, numerous historical ancient Near Eastern kings propagated myths about their humble origins as gardeners. ${ }^{44}$ In reflection of the cosmic order, the king's palace is the heart of the world and the focal point of communication between gods and humans. ${ }^{45}$ Hence, palaces tend to boast elaborate gardens, which symbolize unbreakable divine favor and evoke the "sacred marriage" between the king and goddess. ${ }^{46}$

11 Herodotus describes such a beautiful palace at Celaenae in Phrygia, ${ }^{47}$ which Xenophon had also visited. ${ }^{48}$ The Persians were especially adept at creating such gardens which were known as Paradises ( $\pi \alpha \rho \alpha ́ \delta \varepsilon l \sigma o l)$ and were invested with considerable political significance. ${ }^{49}$ Xenophon describes how Astyages the Mede offered his grandson Cyrus the privilege of hunting in his paradise as a gesture of recognizing his legitimacy - the boy was destined to be a king. ${ }^{50}$ Xenophon is also appreciative of the relationship between kingship and agriculture, as exemplified in the tale of Cyrus the Younger and his paradise at Sardis, related in the Oeconomicus. ${ }^{51}$ There, we read that, when Lysander 
was shown around this magnificent royal garden, he was surprised to realize that the king himself toiled regularly in the garden and was responsible for the impeccable alignment of its rows. According to Critobulus, another of Socrates' interlocutors in the treatise, the king "pays as much attention to husbandry as to warfare," ${ }^{52}$ a statement to which Socrates responds as follows: ${ }^{53}$

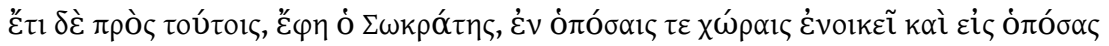

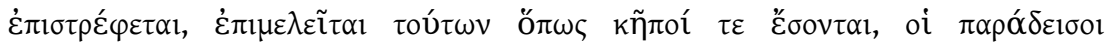

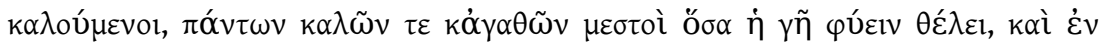

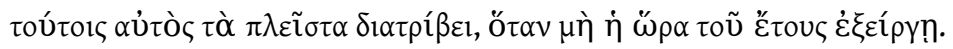

In all the districts [...] he [= the king] resides in and visits he takes care that there are 'paradises,' as they call them, full of all the good and beautiful things that the soil will produce, and in this he himself spends most of his time, except when the season precludes it.

Cyrus $^{54}$ swears by the Sun-god, who often poses as the patron of ancient Near Eastern kings, ${ }^{55}$ that he engages daily in some task of war or agriculture. In response, Lysander concedes that Cyrus deserves his happiness on account of his virtues. ${ }^{56}$ At Oeconomicus 5.2, Socrates explains that the earth, typically identified with the fertility goddess, as we saw in the "sacred marriage" context, yields to the cultivators "luxuries to enjoy"

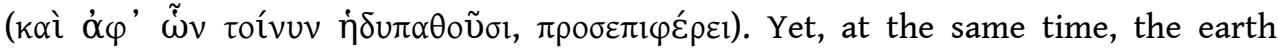
"stimulates armed protection of the country on the part of the husbandmen, by nourishing her crops in the open for the strongest to take." ${ }^{57}$ Moreover, she "willingly teaches righteousness to those who can learn; for the better she is served, the more good things she gives in return." 58

13 Xenophon's observations, put in the mouth of Socrates, accurately explain the ideology of the "sacred marriage" often allegorized in ancient Near Eastern myths about good and bad farmers and/or gardeners who please or displease the goddess with their labor. In these tales, the king poses as the farmer/gardener and lover of the goddess in the footsteps of her consort Dumuzi ${ }^{59}$ If the king is successful in continuously pleasing the goddess, he will maintain his position. If not, there will be a breakdown in their relationship. Indeed, she is often discussed in connection with a usurper, who is likely to take over as the next king and, of course, will become her next 'lover'. The concept is made clear in several mythic tales, including the myth of the gardener Shukaletuda. ${ }^{60}$ Shukaletuda, we are told, enjoys the trust of the goddess for a brief period and is appointed as her gardener, but he uproots the plants of her sacred garden and rapes the goddess while she is asleep in her garden. As soon as Inanna wakes up and realizes what has happened to her, she vows that the Sumerian people, among whom Shukaletuda hides himself to avoid divine retribution, will "drink blood." In other words, her punishment of the people will come in the form of an enemy army that, under her auspices, devastates every city it attacks. ${ }^{61}$ In similar spirit, at Oeconomicus 5.19-20, Socrates admits to Critobulus that the gods control the operations of agriculture no less than those of war.

\section{Sacred Prostitution}

As mentioned previously, the "sacred marriage" custom is generally studied in tandem with that of "cultic" or "sacred prostitution," at which point Herodotus' description of the "shameful" Babylonian custom (1.199) is often discussed. According to this locus, at least if we follow the scholarly consensus on the translation of the passage, every 
woman ought to have sex with a stranger once in her life in honor of Mylitta, the Assyrian equivalent of Aphrodite. More recently, however, our understanding of the phenomenon of "cultic/sacred prostitution" has been revisited, with some scholars, including Assante, maintaining that there is no hard evidence for "sacred prostitution" in Mesopotamia. ${ }^{62}$ In the following pages, we discuss Herodotus' attitude to the phenomenon of prostitution to demonstrate that he did not find it shameful per se. Rather, this interpretation of Herodotus' 1.199 lies mainly in the later rehashing of his description in Roman times. Finally, we suggest that a different appreciation of the word order of the relevant passage could allow much more choice to the Babylonian women compared to our current understanding of it, which privileges what is generally accepted as the obligatory nature of the custom. In line with this new point of view, Herodotus only wished to castigate human superstition and the desperate, naïve and misguided attempts of humans to appeal to the gods to gratify their desires. He did not wish to single out the moral standards of the Babylonians, but used the example of the Babylonians as symptomatic of human credulity more generally, something of which the Greeks could also be guilty. Let us start with the passage in Herodotus that is regularly invoked:

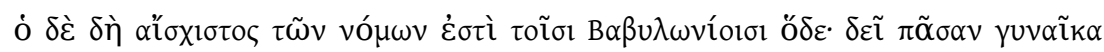

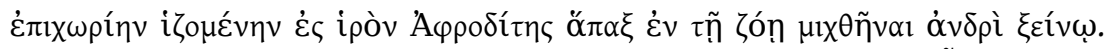

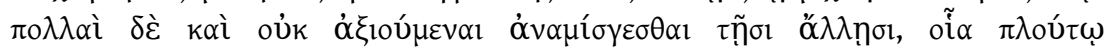

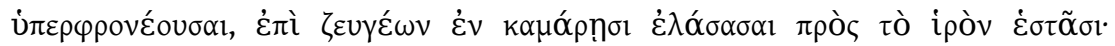

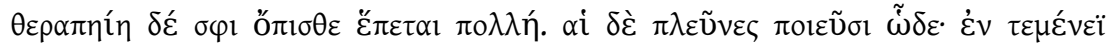

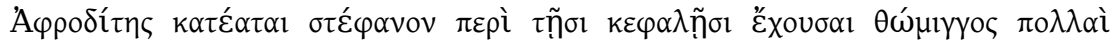

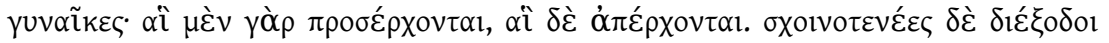

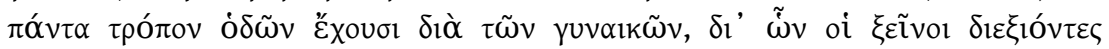

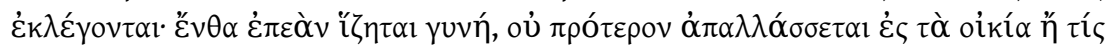

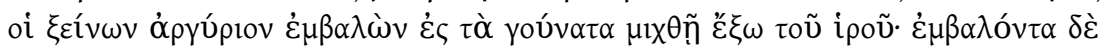

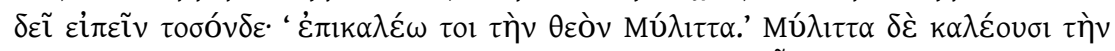

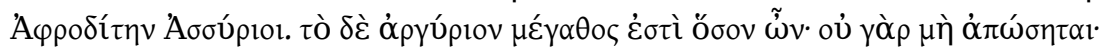

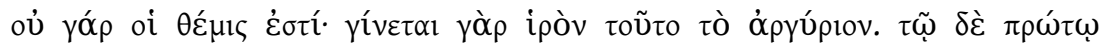

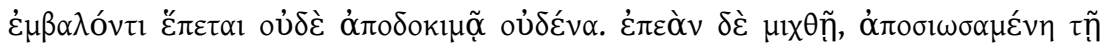

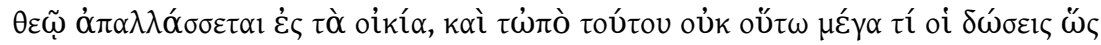

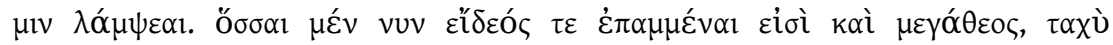

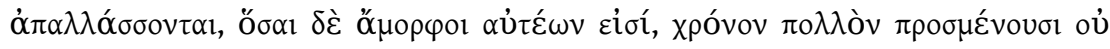

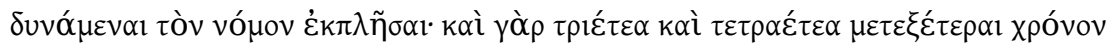

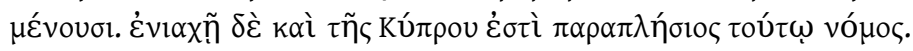

The foulest Babylonian custom is that which compels every woman of the land to sit in the temple of Aphrodite and have intercourse with some stranger once in her life. Many women who are rich and proud and disdain to mingle with the rest, drive to the temple in covered carriages drawn by teams, and stand there with a great retinue of attendants. But most sit down in the sacred plot of Aphrodite, with crowns of cord on their heads; there is a great multitude of women coming and going; passages marked by lines run every way through the crowd, by which the men pass and make their choice. Once a woman has taken her place there, she does not go away to her home before some stranger has cast money into her lap, and had intercourse with her outside the temple; but while he casts the money, he must say, "I invite you in the name of Mylitta" (that is the Assyrian name for Aphrodite). It does not matter what sum the money is; the woman will never refuse, for that would be a sin, the money being by this act made sacred. So she follows the first man who casts it and rejects no one. After their intercourse, having discharged her sacred duty to the goddess, she goes away to her home; and thereafter there is no bribe however great that will get her. So then the women that are fair and tall are 
soon free to depart, but the uncomely have long to wait because they cannot fulfil the law; for some of them remain for three years, or four. There is a custom like this in some parts of Cyprus. ${ }^{63}$ the fact that, a few lines above, at 1.196, he discussed it as an excellent device, which shrewd Babylonians had used in the past for marrying off their daughters. After the conquest of their land and the general poverty suffered in its aftermath, the Babylonians supposedly often prostituted their girls, especially those of the lower classes, in the hope of some relief from poverty.$^{64}$ Although the practice had fallen into disuse by Herodotus' day, we are told, he passes no judgment, but solely records the information he had been given. So, what is the factor that makes the custom described at 1.199 so shameful? Previous explanations of the institution include cases of female infertility that (even if temporary) always posed a threat to the social status of women, or the obscure case of the kezertu women, who could be of high status, in accordance with Herodotus' report, but prostituted themselves to fulfill debt-related obligations. ${ }^{65}$ MacLachlan suggests that Herodotus documented "this most shameful practice" to demonstrate the moral superiority of the Greeks, who did not participate in such rituals. ${ }^{66}$ Strabo, writing in the first century BCE, seems to have read this passage in exactly this spirit. He wrote at 16.1.20:67

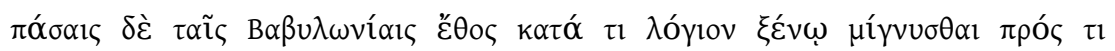

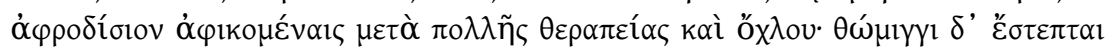

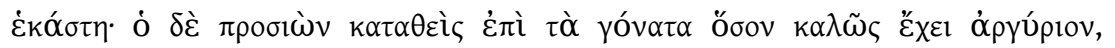

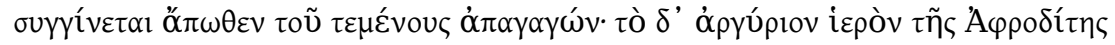

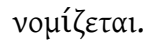

There is a custom prescribed by an oracle for all the Babylonian women to have intercourse with strangers. The women repair to a temple of Aphrodite, accompanied by numerous attendants and a crowd of people. Each woman has a cord round her head; the man approaches a woman, and places on her lap as much money as he thinks proper; he then leads her away to a distance from the sacred grove, and has intercourse with her. The money is regarded as consecrated to Aphrodite.

In relating the custom of "sacred prostitution" among the Armenians, Strabo made another reference to Herodotus, this time by name. His text at 11.14 .16 reads: ${ }^{68}$

Both the Medes and Armenians have adopted all the sacred rites of the Persians, but the Armenians pay particular reverence to Anaitis, and have built temples to her honor in several places, especially in Acilisene. They dedicate there to her service male and female slaves; in this there is nothing remarkable, but it is surprising that persons of the highest rank in the nation consecrate their virgin daughters to the goddess. It is customary for these women, after being prostituted for a long period at the temple of Anaitis, to be disposed of in marriage, no one

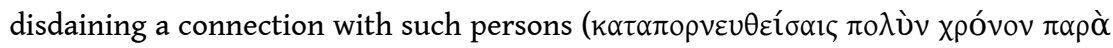

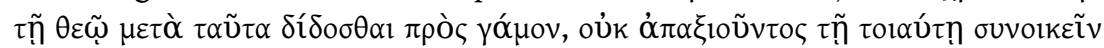

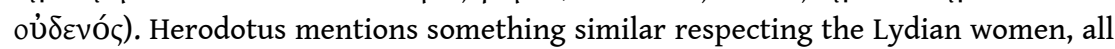

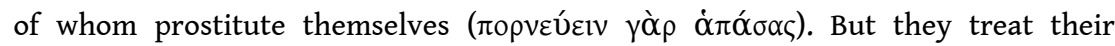
paramours with much kindness, they entertain them hospitably, and frequently make a return of more presents than they receive, being amply supplied with means derived from their wealthy connections. They do not admit into their dwellings accidental strangers, but prefer those of a rank equal to their own.

Pompeius Trogus, a contemporary of Strabo, seems to have misread Herodotus in exactly the same way, pointing to a kind of "orientalism," to use Said's term, ${ }^{69}$ which held an appeal for the Roman upper classes in the first century BCE. In his version of 
the Babylonian customs, Herodotus (1.199, final line) adds that, in Cyprus, Aphrodite was worshipped in similar terms. ${ }^{70}$ Pompeius Trogus (Epit. 18.5) seems to enhance Herodotus' reference to this custom by claiming that

there was a custom among the Cyprians to send young girls down to the sea-shore on specific days before their marriage to earn money for their dowry by prostitution (dotalem pecuniam quaesituras in quaestum), and to offer Venus libations for the preservation of their virtue in the future. ${ }^{71}$

In the first century CE, Curtius Rufus (5.1.36-38) discussed the unparalleled moral corruption (nihil urbis eius corruptius moribus) of the Babylonians, with specific references to their habit of prostituting their girls and women: liberos coniugesque cum hospitibus stupro coire, modo pretium flagitii detur, parentes maritique patiuntur. It is worth noting that Curtius omits the religious framework in which Herodotus made his comments and simply focuses on the corruptible nature of the people, now additionally presented as drunkards who have surrendered to their innate lasciviousness: Babylonii maxime in vinum et, quae ebrietatem sequuntur, effusi sunt. He states that this customary display of immorality, which included the appearance of naked married women (matronae) and even girls (virgines) at dinner parties, posed a major threat to the character of Alexander the Great and his men. Indeed, we are told that Alexander spent more time there than in any other of his conquests, and that military discipline was seriously undermined as a result of this extended stay. ${ }^{72}$

Furthermore, as Budin has pointed out, the only two inscriptions that provide evidence of "sacred prostitution" come, not from Mesopotamia, but from Roman Tralleis in Caria, where women describing themselves as pallakides make dedications to Zeus. ${ }^{73}$ Notably one of these women, L. Aurelia Aemilia, says that she became a pallakē because of an oracle. The term pallake is understood as somewhere between a wife and a concubine ${ }^{74}$ and is probably used here as a term evoking a "sacred marriage" context so as to refer to the devotion of these women to their cultic duties. Still, Ramsay understood the term pallake to mean a "sacred prostitute." 75 Ramsay was influenced in his interpretation by Strabo 12.3.36 and 17.1.46, which loci discuss "sacred prostitution" in the Black Sea and Egypt respectively. Furthermore, Robert accepted Ramsay's interpretation and referred to the dedication as "émanant d'une prostituée sacrée."

The important phrase that led scholars to think that Strabo's 17.1.46 refers to "sacred

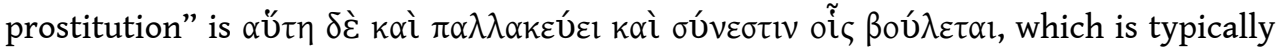
translated as "she prostitutes herself with whom she pleases." 77 However, the

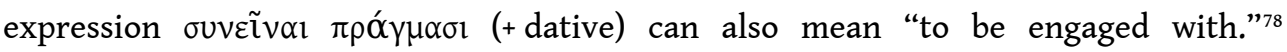
Accordingly, by offering a totally non-sexualized translation of the text, Budin suggests that the term pallades, taken to correspond to the pallakides of the Roman inscriptions, probably refers to young girls serving as handmaidens of the goddess until menstruation made them ready for marriage. ${ }^{79}$ Hence, these servants of the goddess, dedicated by their fathers and often of high social status, did not "have sex with whomever they wished," as Strabo's text is often translated and understood, but rather "engaged in whatever service to the goddess they chose." As will be argued here, 1.199 of Herodotus' Histories may represent another example of this tendency to adopt translations that entail pejorative insinuations about the morality of Near Eastern cultures in antiquity.

21 The other relevant text of Strabo (12.3.36) refers to the city of Comana in the Black Sea, which he compares to Corinth. ${ }^{80}$ His lines were understood to provide clear evidence 
for expensive temple prostitutes at Corinth, whose fees McLachlan estimates to have cost up to 1,000 drachmas..$^{81}$ Likewise, Ferguson insists that "not only was prostitution a recognized institution, but through the influence of the fertility cults of Asia Minor, Syria, and Phoenicia it became a part of the religious rites at certain temples." ${ }^{82} \mathrm{He}$ adds, by way of example, that 'there were one thousand 'sacred prostitutes' at the temple of Aphrodite at Corinth." However, Strabo is probably reporting a custom of the past with some exaggeration - he says that the temple had "more than a thousand temple-slaves," even though the location, as Beard and Henderson point out, would not have been large enough to accommodate so many slaves. ${ }^{83}$ Here, the phrases that convinced scholars that Corinthian women were engaged in "sacred prostitution" was

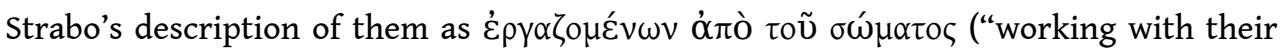
bodies" but often translated as "make a gain from their persons" ${ }^{84}$ ) and the use of the word hetairai for the multitude of women who were dedicated to Aphrodite ( $\tau$ ò $\pi \lambda \tilde{\eta} \theta$ os

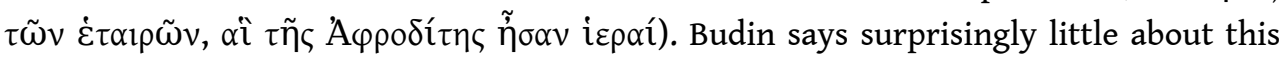
passage given her conviction that ancient "sacred prostitution" was a myth. A closer reading, however, indicates that the women's labor is mentioned in association with the cultivation of the vines, which could well be referring to them working in the fields as part of their cultic engagements. Ancient temples often controlled lands used for the sustenance of their cultic personnel and even for gain, similar to the way modern monasteries operate. As for their address as hetairai, a word with undeniable sexual connotations in ancient Greek texts, ${ }^{85}$ it could be argued that Strabo uses the term similarly to the word pallake in the previous text. It seems apparent that sexually charged terms were used to evoke the devotion of these servants to their divine patrons - Zeus in the previous text, Aphrodite here. Inanna was also known as the hierodule (nu-gig-an-na) of An, a cultic title which Beaulieu interpreted as indicating that "Inanna is also the mistress of An, in addition to being his wife and daughter." ${ }^{86}$ Yet, given the metaphorical tone employed in ancient Near Eastern literary texts and inscriptions, to be the "companion" or the "attendant" of a god does not imply prostitution.

Another source allegedly depicting "sacred prostitution" at Corinth is Pindar (fr. $122=$ Athen. 13.573e-f), ${ }^{87}$ a poem commissioned to acknowledge Xenophon's fulfillment of his vow to dedicate 100 "prostitutes" to Aphrodite's temple in Corinth if he won at the Olympic Games. But, as Budin suggests, Pindar refers to his poem as a skolion, a drinking song and, hence, unsuitable for a religious dedication. ${ }^{88}$ Budin understands Pindar's reference to the grove of Aphrodite to mean the andron, the men's space, where they probably held a party after his victory involving prostitutes. She further points out that it was Athenaeus who, in citing Pindar's poem, added that it related to an old Corinthian custom allegedly presided over by Aphrodite Urania, thus leading modern scholars in reading the poem as a reference to "sacred prostitution." ${ }^{89}$ However, Budin's interpretation of Pindar's skolion, which supposedly refers to a celebratory orgy after an Olympic victory, seems to be equally farfetched. It is more likely, in our view, that Xenophon vouched that he would dedicate a number of cultic servants to the goddess if she favored him and granted him victory. This explanation is perfectly compatible with the Athenian Xenophon's discussion of the goddess and her royal worshippers discussed at the beginning of the article. Moreover, sports and war are often conflated in ancient Greek thought since both involved the pursuit of manly excellence ( $\dot{\alpha} \rho \varepsilon \tau \mid \eta)$. Our interpretation does not discount the fact that prostitution was a widespread phenomenon of the ancient world, often practiced around temples that 
attracted numerous visitors, especially during festive days; yet, by drawing attention to the use of explicit sexual language to describe religious devotion in antiquity, from the most sensual near eastern examples, discussed above, to the survival of the trend in Greek cultic titles, we seek to challenge the prevailing historical appreciation of the institution of "sacred prostitution," which is based, by and large, on a rather inflexible reading of a handful of ancient texts (all analyzed in the current article).

\section{Back to Herodotus 1.199}

So far, our analysis indicates that Herodotus, despite being arguably misread, by ancient writers and modern scholars alike, did not necessarily refer to organized "sacred prostitution," but to a custom that he found shameful because it involved women who were not permanent members of the cultic personnel of Ishtar's temple at Babylon. The fact that the women wore wreaths made of rope signifies their special status as being under the influence of the goddess, probably for the duration of their pilgrimage, regardless of whether we see this rope as a symbol of the feminine girdle (also worn by the goddess). ${ }^{90}$ In the Agushaya hymn exalting Ishtar, the goddess holds in her hand the nose-rope of heaven and earth (sier-ret AN-e u KI-tim $=$ sier-ret same ${ }^{e} u$ ersieti $\left.{ }^{t i}\right),{ }^{91}$ while she is also depicted in art as using a rope to lead her lion. ${ }^{92}$ Likewise the holy jump-rope of Inanna/Ishtar is part of a dance enacted in her festivals. ${ }^{93}$ Hence, in all probability, the women dedicating themselves to the goddess, even for a short period of their lives, believed that they shared her qualities, or at least hoped to be benefited by her influence to the point of being willing to sleep with a stranger. In our view, it is the religious credulity of the Babylonians that Herodotus primarily castigates, rather than what was perceived by later Greco-Roman authors as a barbaric custom.

Herodotus' relationship with his sources has been long discussed in the bibliography, with Fehling arguing that the citation of his sources should be treated as a literary device (though he does not argue that Herodotus invented all of the stories he reported), ${ }^{94}$ and Pritchett accusing him of totally fabricating the details of his stories. ${ }^{95}$ Although the modern historians' debate on Herodotus' veracity and the reliability of his sources has tirelessly focused on his physical description of the city of Babylon, not the customs he reported, Rollinger has defended Herodotus' familiarity with Near Eastern traditions and his accurate transmission of them to his Greek-speaking audiences. ${ }^{96}$ Thus, if we entertain the idea that Herodotus reported fairly accurately the tradition of temple prostitution at Babylon, his hyperbolic reference to the need of "every local woman" to prostitute herself is likely designed to emphasize the credulity of the people who observed this custom - though not on the basis of their ethnic origin. ${ }^{97}$

Furthermore, there may be something to be said about our usual translation of the relevant Herodotean text. Although Strabo clearly refers to all women performing this rite, Herodotus' text may not necessarily support this view. The phrase $\delta \varepsilon \tilde{\imath} \pi \tilde{\alpha} \sigma \alpha v$

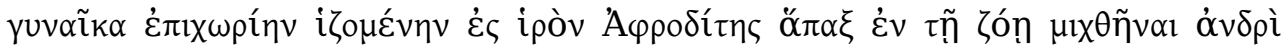

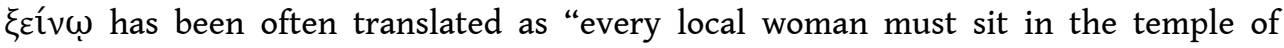
Aphrodite and have intercourse with some stranger once in her life," which means that

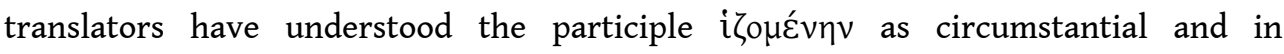
connection with the impersonal verb $\delta \varepsilon \tilde{\imath} .{ }^{98}$ Of course, in ancient Greek, when an 
obligation or command concerns two actions, one of the actions tends to be subordinated and presented as a circumstantial participle..$^{99}$ On occasion, the participle has been understood as temporal but, again, translators assumed that the ritual applies to all women. ${ }^{100}$ Herodotus employs the combination of the impersonal $\delta \varepsilon \tilde{\imath}+$ infinitive + participle nineteen times in the Histories; ${ }^{101}$ sixteen of these participles are circumstantial, but only four can be understood as expressing one of two actions that must be carried out (the other action being expressed by an infinitive).$^{102}$ On four occasions, Herodotus employs circumstantial participles to denote manner/means; ${ }^{103}$ on two, to denote time, ${ }^{104}$ on three, cause; ${ }^{105}$ one is merely descriptive, ${ }^{106}$ and one expresses condition. ${ }^{107}$ Herodotus also uses this structure with three attributive participles, accompanied, as is the case often, by the article. ${ }^{108}$ The participle in the

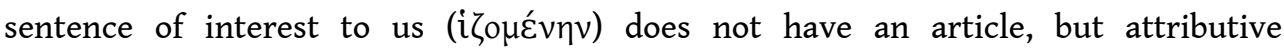
participles are not always accompanied by the article, especially when used in indefinite sense. ${ }^{109}$ Herodotus does use attributive participles without the article elsewhere in his work. ${ }^{110}$ If, however, we appreciate the participle as attributive, translating as "every local woman sitting" or even "seated," given that the verb is middle-passive, ${ }^{111}$ this translation implies that not every Babylonian woman ought to sleep with a stranger, but only those who chose to sit at the temple for the purposes of securing divine favor ${ }^{112}$ - something which, if we read Herodotus with nuance, can only be done once in a lifetime. From this point of view, it would make more sense for Herodotus to castigate as shameful a custom that permits some otherwise ordinary women to think that they can claim divine favor by sleeping with a stranger.

In conclusion, it seems that Herodotus' references to the customs of "sacred marriage" and "sacred prostitution" have excited the imagination of both his ancient and modern readers. That said, the interpretations of the texts in question often reflect the readers' cultural biases rather than those of Herodotus. In second guessing his authorial intentions, it has often been assumed, particularly by those who are certain that there is only a single way to read his text and that all intermediary authors transmitted this reading accurately, that Herodotus was keen to support the cultural superiority of the Greeks against their barbarian neighbors, or that he did not evaluate his sources adequately. However, in light of recent research that highlights previous hastily made readings of authors such as Strabo (see above for Budin's alternative interpretation of 17.1.46 and ours of 8.6.20), it seems likely that our views on Herodotus' cultural bias have been influenced by later Greco-Roman readings of the Histories. From this point of view, a more nuanced reading of Herodotus 1.181.5-182.1-2 and 1.199 would suggest that, in reporting the customs of "sacred marriage" and "sacred prostitution," Herodotus probably wished, in the main, to castigate human prejudice and credulity rather than the lack of sophistication of the non-Greek societies upholding these customs. 


\section{BIBLIOGRAPHY}

S. ACKERMAN, Under Every Green Tree: Popular Religion in Sixth-Century Judaism, Atlanta, 1992.

E. ANAGNOSTOU-LAOUTIDES, In the Garden of the Gods. Models of Kingship from the Sumerians to the Seleucids, London/New York, 2017.

S. ARO, R.M. WHITING (eds.), The Heirs of Assyria, Helsinki, 2000.

D. ASHERI, A Commentary on Herodotus I-IV, Oxford, 2007.

D. ASHERI, V. ANTELAMI, Libro 1. La Lidia e la Persia/Erodoto, Milan, 1988.

J. ASSANTE, "The kar.kid/harimtu, Prostitute or Single Woman: A Re-consideration of the Evidence," UF 30 (1998), p. 5-96.

-, "From Whores to Hierodules: The Historiographic Invention of Mesopotamian Female Sex Professionals," in DONOHUE - FULLETON (2003), p. 13-47.

A. AVAGIANNOU, Sacred Marriage in the Rituals of Greek Religion, Bern, 1991.

R.S. BAGNALL, K. BRODERSEN, C.B. CHAMPION, A. ERSKINE, S.R. HUEBNER (eds.), The Encyclopedia of Ancient History, Malden, MA, 2012.

J.C.H. BÄHR, Die Musen des Herodotus von Halicarnassus, Stuttgart, 1868.

Z. BAHRANI, Women of Babylon: Gender and Representation in Mesopotamia, New York, 2001.

-, "The Performative Image: Narrative, Representation, and the Uruk Vase," in EHRENBERG (2002), p. $15-22$.

E.M. BARTOLOMÉ POU, Los nueve libros de la Historia de Heródoto, Madrid, 1989.

M. BEARD, J. HENDERSON, “With This Body I Thee Worship: Sacred Prostitution in Antiquity," Gender and History 9 (1997), p. 480-503.

P.A. BEAULIEU, The Reign of Nabonidus, King of Babylon, 556-539 B.C., New Haven/London, 1989.

-, "Antiquarianism and the Concern for the Past in the Neo-Babylonian Period," Bulletin of the Canadian Society for Mesopotamian Studies 28 (1994), p. 37-42.

-, The Pantheon of Uruk during the Neo-Babylonian Period, Leiden, 2003.

G. BECKMAN, “Plague Prayers of Mursili II,” in HALlO - YOUNGER (2003), p. 156-160.

S.G. BENARDETE, Herodotean Inquiries, The Hague, 1969.

S. BENKO, The Virgin Goddess: Studies in the Pagan and Christian Roots of Mariology, Leiden, 2004.

J. BIDMEAD, The Akitu Festival, Religious Continuity and Royal Legitimation in Mesopotamia, Piscataway, NJ, 2002.

P. BIRD, “Qades-Qadeshim,” in EMERTON (1997), p. 37-80.

S. BLUNDELL, M. WILliAmson (eds.), The Sacred and the Feminine in Ancient Greece, New York, 1998.

F.M.T. BÖHL, “Die Tochter des Königs Nabonids," in FOLKERS, FRIEDRICH, LAUTNER, MILES (1939), p. 151178.

J. воTTÉRO, L'épopée de Gilgamesh, le grand homme qui ne voulait pas mourir, Paris, 1993. 
B. BREITENBERGER, Aphrodite and Eros: the Development of Greek Erotic Mythology, London, 2013.

J.N. BREMMER, The Rise and Fall of the Afterlife, London/New York, 2002.

K. BRINGMANN, "The King as Benefactor: Some Remarks on Ideal Kingship in the Age of Hellenism," in BULLOCH, GRUEN, LONG, STEWART (1993), p. 7-24.

S. BUDIN, The Origin of Aphrodite, Bethesda, MD, 2003.

-, "Sacred Prostitution in the First Person," in FARAONE - MCCLURE (2006), p. 77-92.

-, The Myth of Sacred Prostitution in Antiquity, New York, 2008.

A.W. BULLOCH, E.S. GRUEN, A.A. LONG, A. STEWART (eds.), Images and Ideologies: Self-definition in the Hellenistic World, Berkeley, 1993.

W. BURKERT, Ancient Mystery Cults, Cambridge, MA, 1987.

S.A.L. BUTLER, Mesopotamian Conceptions of Dreams and Dream Rituals, Münster, 1998.

A. CHAPMAN, "Gudea and the Gods: Intersecting Policy and Prophecy," Studia Antiqua 6 (2008),

p. $41-49$.

D. CHARPIN, “' 'I am the Sun of Babylon:' Solar Aspects of Royal Power in Old Babylonian Mesopotamia," in HILL, JONES, MORALES (2013), p. 65-96.

M.W. CHAVAlas (ed.), The Ancient Near East: Historical Sources in Translation, Oxford, 2006.

M.R. CHRIST, “Herodotean Kings and Historical Inquiry,” in MUNRO (2013), p. 212-252.

I. CLARK, "The Gamos of Hera," in BLUNDELL - WILLIAMSON (1998), p. 13-26.

A.C. COHEN, The Cultic Calendars of the Ancient Near East, Bethesda, MD, 1993.

D. COLLON, “Babylonian Seals," in LEICK (2007), p. 95-123.

J. COOPER, "Sacred Marriage and Popular Cult in Early Mesopotamia," in MATSUSHIMA (1993), p. 8196.

—, "Sex and the Temple," in KANIUTH, LOHNERT, MILLER, and OTTO (2013), p. 49-58.

V.E. CRAWFORD, “The Third Millennium B.C.," Metropolitan Museum of Art Bulletin 18 (1960), p. 245252.

S. DALLEY, "Ancient Mesopotamian Gardens and the Identification of the Hanging Gardens of Babylon Resolved," Garden History 21 (1993), p. 1-13.

J. DAY (ed.), King and Messiah in Israel and the Ancient Near East, Sheffield, 1998.

M. DEJONG ELLIS, "Observations on Mesopotamian Oracles and Prophetic Texts: Literary and Historiographic Considerations," Journal of Cuneiform Studies 41 (1989), p. 127-186.

T. DERKS, N. ROYMANS (eds.), Ethnic Constructs in Antiquity: the Role of Power and Tradition, Amsterdam, 2009.

A.A. DonohuE, M.D. fulleton (eds.), Ancient Art and Historiography, Cambridge, 2003.

J.M. DURAND, Archives Épistolaires de Mari I/1, Paris, 1988.

D.O. EDZARD, Gudea and His Dynasty, RIME 3/1, Toronto, Buffalo, London, 1997.

S.K. EDDY, The King is Dead: Studies in the Near Eastern Resistance to Hellenism, 334-31 BC, Lincoln, NE, 1961. 
E. EHRENBERG (ed.), Studies in Honor of Donald P. Hansen, Winona Lake, ID, 2002.

J.A. EMERTON (ed.), Congress Volume Cambridge 1995, Leiden, 1997.

A. FALKENSTEIN, “Akiti-Fest und akiti-Festhaus," in FRIEDRICH, VON KIENLE, MOORTGAT (1959), p. 147182.

C.A. FARAONE, L.K. MCCLURE (eds.), Prostitutes and Courtesans in the Ancient World, Madison, 2006.

D. FEHLING, Herodotus and his Sources: Citation, Inversion and Narrative Art, Leeds, 1989.

E. FERGUSON, Backgrounds of Early Christianity 2, Grand Rapids, MI, 1993.

T. FOLKERS, J. FRIEDRICH, J.G. LAUTNER, J.C. MILES (eds.), Symbolae ad iura orientis antiqui pertinentes Paulo Koschaker dedicatae, Leiden, 1939.

B.R. FOSTER, Before the Muses: An Anthology of Akkadian Literature, Bethesda, MD, 1996.

B.R. FOSTER (ed.), The Epic of Gilgameš, New York, 2001.

H. FRANKFORT, Kingship and the Gods. A study of Ancient Near Eastern Religion as the Integration of Society and Nature, Chicago, 1948.

D. FRAYNE, “Gilgameš, Enkidu, and the Netherworld,” in FOSTER (2001), p. 129-143.

D.N. FREEMAN (ed.), The Anchor Bible Dictionary, New York, 1992.

J. FRIEDRICH, R. VON KIENLE, A. MOORTGAT (eds.), Johannes Friedrich Festschrift zum 65. Geburtstag am 27, Heidelburg, 1959.

C.J. GADD, Ideas of Divine Rule in the Ancient East, Oxford, 1948.

M.B. GARRISON, “Antiquarianism, Copying, Collecting,” in POTTS (2012), p. 27-47.

H. GOEDICKE, J.J.M. ROBERTS (eds.), Unity and Diversity: Essays in History, Literature, and Religion of the Ancient Near East, Baltimore, 1975.

W.W. GoodWIN, Syntax of the Moods and Tenses of the Greek Verb, London, 1889.

-, A Greek Grammar, London et al., 1965 (originally London, 1879).

B. GRONEBERG, Lob der Ištar: Gebet und Ritual an die altbabylonische Venusgöttin, Groningen, 1997.

A.D. GODLEY, Herodotus I., Loeb Classical Library, Cambridge, MA, 1920.

A.S.F. Gow, Machon. The Fragments, Cambridge, 1965.

A. GRIFFITHS, "Kissing Cousins: Some Curious Cases of Adjacent Material in Herodotus," in LURAGHI (2001), p. 161-178.

O.R. GURNEY, “The Babylonians and Hittites,” in LOEWE - BLACKER (1981), p. 142-173.

J. HALL, Hellenicity: Between Ethnicity and Culture, Chicago, 2002.

W.W. HALLO, The World's Oldest Literature: Studies in Sumerian Belles-Lettres, Leiden, 2010.

W.W. HALLO, K.L. YOUNGER (eds.), The Context of Scripture Volume 1: Canonical Compositions from the Biblical World, Leiden/Boston, 2003.

W.W. HALlo, W. SIMPSON, The Ancient Near East: A History, Fort Worth, TX, 1997.

H.C. HAMILTON, W. FALCONER, The Geography of Strabo. Literally translated with notes III, London, 1957. 
R. HARRIS, Gender and Aging in Mesopotamia: The Gilgameš Epic and Other Ancient Literature, Norman, 2000.

F. HARTOG, The Mirror of Herodotus: The Representation of the Other in the Writing of History, trans.

J. LLOYD, Berkeley, CA, 1988.

W. HEINEMANN, Xenophon in Seven Volumes, Cambridge, MA, 1979.

G.L. HERSEY, Falling in Love with Statues: Artificial Humans from Pygmalion to the Present, Chicago, 1999.

J.A. HILl, P. JONES, A.J. MORALES (eds.), Experiencing Power, Generating Authority: Cosmos, Politics, and the Ideology of Kingship in Ancient Egypt and Mesopotamia, Philadelphia, 2013.

L.L. HOLLAND, "Marriage, Sacred, Greece and Rome," in BAGNALL, BRODERSEN, CHAMPION, ERSKINE, HUEBNER (2012), DOI: 10.1002/9781444338386.wbeah17257.

S.H. HООКE (ed.), Myth, Ritual and Kingship: Essays on the Theory and Practice of Kingship in the Ancient Near East and in Israel, Oxford, 1958.

S. HORNBLOWER, Herodotus. Histories Book V, Cambridge, 2013.

T. HUBBARD (ed.), A Companion to Greek and Roman Sexualities, Malden, MA, 2014.

V. HUROWITZ, "Some Literary Observations on the Šitti-Marduk Kudurru (BBSt6)," Zeitschrift für Assyriologie und Vorderasiatische Archäologie 82 (1992), p. 39-59.

J.M. HUSSER, Dreams and Dream Narratives in the Biblical World, trans. J.M. MUNRO, Sheffield, 1999.

Th. JACOBSEN, “Religious Drama in Ancient Mesopotamia,” in GOEDICKE - ROBERTS (1975), p. 65-97.

E.O. JAMES, Seasonal Feasts and Festivals, New York, 1962.

H.L. JONES, The Geography of Strabo V: Books 10-12, Cambridge, MA (Loeb Classical Library 211), 1928.

-, The Geography of Strabo VII: Books 15-16, Cambridge, MA (Loeb Classical Library 241), 1930.

-, The Geography of Strabo VIII: Book 17, Cambridge, MA (Loeb Classical Library 267), 1932.

P. JONES, "Embracing Inanna: Legitimation and Mediation in the Ancient Mesopotamian Sacred Marriage Hymn Iddin-Dagan A," JAOS 123 (2003), p. 291-302.

S.I. JOHNSTON (ed.), Religions in the Ancient World: A Guide, Cambridge, Mass., 2004.

A. KANIUTH, A. LOHNERT, J.L. MILleR, A. OTTO (eds.), Tempel Im Alten Orient. 7 Colloquium, München 2009, Wiesbaden, 2013.

J. KLEIN, The Royal Hymns of Šulgi King of Ur: Man's Quest for Immortal Fame, Philadelphia, 1981.

-, “Sacred Marriage," in FREEMAN (1992), p. 866-870.

J. KIM, Incubation as a Type-Scene in the Aqhatu, Kirta and Hannah Stories. A Form-Critical and Narratological Study of KTU 1.14 I-1.15 III, 1.17 I-II, and 1 Samuel 1:1-2:11, Leiden, 2011.

D. KONSTAN, “Between Courtesan and Wife: Menander's Perikeiromene," Phoenix 41 (1987), p. 122139.

S.N. KRAMER, Sumerian Mythology: Study of Spiritual and Literary Achievement in the Third Millennium B.C., Philadelphia, PA, 1944.

L. KURKE, "Pindar and the Prostitutes, or Reading Ancient 'Pornography,' " Arion 4 (1996), p. 49-75.

-, "Inventing the Hetaira: Sex, Politics and Discursive Conflict in Archaic Greece." ClAnt 16

(1997), p. 106-150. 
W.G. LAMBERT, "Kingship in Ancient Mesopotamia," in J. DAY (ed.), King and Messiah in Israel and the Ancient Near East, 1998, Sheffield, p. 54-70.

P. LAPINKIVI, The Sumerian Sacred Marriage in the Light of Comparative Evidence, Helsinki, 2004.

-, "The Sumerian Sacred Marriage and its Aftermath in Later Sources," in NISSINEN - RISTO (2008), p. 7-41.

J. LARSON, “Sexuality in Greek and Roman Religion,” in HUBBARD (2014), p. 214-229.

D. LATEINER, The Historical Method of Herodotus, Toronto, 1989.

P.-E. LEGRAND, Hérodote: Histoires. Livre I, Paris, 1932.

G. LEICK (ed.), The Babylonian World, London/New York, 2007.

B. LINCOLN, “Epilogue," in JOHNSTON (2004), p. 657-667.

M. LOEWE, C. BLACKeR (eds.), Divination and Oracles, London, 1981.

N. LURAGHI (ed.), The Historian's Craft in the Age of Herodotus, Oxford, 2001.

B. MACLACHLAN, “Sacred Prostitution and Aphrodite," SR 21 (1992), p. 145-162.

H.J. MARSMAN, Women in Ugarit and Israel: Their Social and Religious Position in the Context of the Ancient Near East, Leiden, 2003.

E. MATSUSHIMA, “Le Rituel Hiérogamique de Nabû,” Acta Sumerologica 9 (1987), p. 131-175.

E. MATSUSHima (ed.), Official Cult and Popular Religion in the Ancient Near East, Heidelberg, 1993.

S.M. MAUL, "Divination Culture and the Handling of the Future," in LEICK (2007), p. 361-373.

S.C. MELVILLE, “The Autobiography of Adad-guppi,” in chavalas (2006), p. 390-391.

J.D. MIKALSON, Herodotus and Religion in the Persian Wars, Chapel Hill, NC, 2003.

J. MINER, "Courtesan, Concubine, Whore: Apollodorus' Deliberate Use of Terms for Prostitutes," AJPh 124 (2003), p. 19-38.

R. MOdiano, L. SEARLE, P.L. SHILlingSBURG (eds.), Voice, Text, Hypertext: Emerging Practices in Textual Studies, Seattle, 2004.

M.S. MOORE, The Balaam Traditions: Their Character and Development, Atlanta, 1990.

M.H. MUNN, The Mother of the Gods, Athens, and the Tyranny of Asia. A Study of Sovereignty in Ancient Religion, Berkeley, 2006.

R. MUNRo (ed.), Herodotus: Volume 1. Herodotus and the Narrative of the Past, Oxford, 2013.

M. NISSINEN, “Akkadian Rituals and Poetry of Divine Love,” in WHITING (2001), p. 93-136.

M. NISSINEN, U. RISTO (eds.), Sacred Marriages: The Divine-Human Sexual Metaphor from Sumer to Early Christianity, Winona Lake, ID, 2008.

S. NOEGEL, "Scribal Activity in the Ancient Near East," in MODIANO, SEARLE, SHILLINGSBURG (2004), p. 133-143.

-, "Greek Religion and the Ancient Near East," in OGDEN (2007), p. 21-37.

K. NYBERG, “Sacred Prostitution in the Biblical World?," in NISSINEN - RISTO (2008), p. 305-320.

R.A. ODEN, "Religious Identity and the Sacred Prostitution Accusation," in ODEN (1987), p. 131-153. 
R.A. ODEN (ed.), The Bible Without Theology: The Theological Tradition and Alternatives to It, San

Francisco, 1987.

D. OGDEN (ed.), The Blackwell Companion to Greek Religion, London, 2007.

T. osHimA, “The Babylonian God Marduk," in LEICK (2007), p. 348-360.

S. PALLIS, The Babylonian Akitu Festival, Copenhagen, 1926.

P. PARKER, Miasma. Pollution and Purification in Early Greek Religion, Oxford, 1983.

S. PEeLS, Hosios. A Semantic Study of Greek Piety, Leiden, 2016.

V. PIRENNE-DELFORGE, L'Aphrodite grecque. Contributions à l'étude de ses cultes et de sa personnalité dans le panthéon archaïque et classique, Liège, 1994 (Kernos, suppl. 4).

-, “'Something to do with Aphrodite': Ta Aphrodisia and the Sacred," in OGDEN (2007), p. 311-323.

-, "Review of Stephanie BUDIN, The Myth of Sacred Prostitution in Antiquity. New York:

Cambridge University Press, 2008," BMCR (2009), http://bmcr.brynmawr.edu/2009/2009-0428.html.

B. PONGRATZ-LEISTEN, "Sacred Marriage and the Transfer of Divine Knowledge: Alliances between the Gods and the King in Ancient Mesopotamia," in NISSINEN - RISTO (2008), p. 43-74.

D.T. POTTS (ed.), A Companion to the Archaeology of the Ancient Near East, Oxford, 2012.

E.J. POWELL, A Lexicon to Herodotus, Cambridge, 1938.

W.K. PRITCHETT, The Liar School of Herodotos, Amsterdam, 1993.

W.M. RAMSAY, “Unedited Inscriptions of Asia Minor,” BCH 7 (1883), p. 258-278.

O.E. RAVN, Herodotus' Description of Babylon, Copenhagen, 1942.

E. REINER, Your Thwarts in Pieces, Your Mooring Rope Cut. Poetry from Babylonia and Assyria, Ann Arbor, 1985.

D. REISMAN, “Iddin-Dagan's Sacred Marriage Hymn," Journal of Cuneiform Studies 25 (1973), p. 185202.

E. ROBBINS, S. SANDAHL (eds.), Corolla Torontonensis. Studies in Honour of Ronald Morton Smith, Toronto, 1994.

L. ROBERT, Études Anatoliennes : Recherches sur les inscriptions grecques de l'Asie Mineure 2, Amsterdam, 1970.

R. ROLLINGER, Herodots babylonischer Logos: eine kritische Untersuchung der Glaubwürdigkeitsdiskussion an Hand ausgewählter Beispiele, Innsbruck, 1993.

-, "Herodotus and the Intellectual Heritage of the Ancient Near East," in ARO - WHITING (2000), p. 65-83.

C.A.P. RUCK, "Documentation," in WASSON, HOFMANN, RUCK (2008), p. 85-136.

W.F. SAGGS, Babylonians, Berkeley/Los Angeles, 2000.

E. SAID, Orientalism, London, 1978.

W. SALlABERger, “Ur III-Zeit,” in SALLABERgER - WESTENHolz (1999), p. 121-414.

W. SALLABERGER, A. WESTENHOlZ (eds.), Mesopotamien: Akkade-Zeit und Ur III-Zeit, Freiburg, 1999. 
J. SASSON, “Mari Dreams,” in SASSON (1984), p. 283-295.

J. SASSON (ed.), Studies in Literature from the Ancient Near East, New Haven, 1984.

C. SCHRADER, Heródoto, Historia, Libros I-II, Madrid, 2000.

$<$ span xml:lang="en" lang="

\section{NOTES}

1. See COOPER (2013), p. 49-50 (who nevertheless offers a new interpretation of Herodotus); cf. HERSEY (1999), p. 77-82, who adds that "sacred marriage" is "sometimes also known as sacred prostitution" (p. 78), a kind of confusion which is pervasive in earlier scholarship on Herodotus; see also PARKER (1983), p. 92-93, esp. n. 77, which describes "sacred marriage" in ancient Greece as a "foreign custom tinged with charlatanism."

2. For example, RAVN (1942), p. 89 argued that "Herodotus has hardly exaggerated the part played by prostitution in the Babylonian community;" cf. SEYMOUR (2014), p. 58 who adds that, on this passage, Herodotus "leaves no room for ambiguity" regarding the custom of prostitution though he expresses doubts about its universal application.

3. THOMAS (2000), p. 90-97 and 104-117 rejects the idea that Herodotus' treatment of Europe and Asia implies a cultural clash between Greeks and barbarians; cf. CRIST (2013), p. 239; HALL (2002), p. 181 argues that Herodotus "does not consistently portray foreign customs in pejorative terms" with reference to 1.196, where Herodotus praises the Babylonians who auction off the most attractive women for marriage to secure a dowry for the less beautiful ones. Yet, see LATEINER (1989), p. 60: "In sum, barbarian ingenuity and diversity do not obscure Herodotus' reasoned belief in Greek mental and moral superiority, a result of climate, poverty, political institutions and competitiveness." GRIFFITHS (2001), p. 167 argues that "the Babylonian material is probably fiction... the fantasy of an outsider projecting Greek Utopian theory onto a realm where it can be imagined as reality." Also, see LATEINER (1989), p. 136, arguing that Herodotus' use of women in the Histories suggests his "unintentional distortion of palace life and harem politics," while on p. 265, n. 32, he claims that Herodotus shows no understanding of Babylonian "sacred prostitution;" in his view, Herodotus is using the irrational behavior of foreign women in the context of the rhetorical tyrant, as these attributes are symptomatic of the dysfunctional oikoi of oriental kings; see also p. 137-140, 156-157 and 171. Also, see BAHRANI (2001), esp. p. 173-179 on the use of Herodotus in $19^{\text {th }}$-century orientalist imagination and the scholarly legacy of this trend.

4. For example, BUDIN (2006), p. 72 states that "sacred prostitution" was only "a literary motif used by one society to denigrate another." See, also, NYBERG (2008), p. 319, who argues that Herodotus "aimed more at shocking his readers than providing them with reliable information," with ASHERI (2007), p. 211 ad 199.1 (with further bibliography), who claims that "what shocked Herodotus was not sacrilege, but the institutionalization of prostitution."

5. Aristotle, Politics, 1285a 19-22 and 1327b 27-29 argues that the peoples of the East lack free will, which is why they are content with being ruled by absolute monarchs. On this, see BRINGMANN (1993), p. 8.

6. The Sumerian "sacred marriage," celebrated during the New Year Festival, is known as the akitu; see LAPINKIVI (2008), p. 1, 11-12, 20-21; SALLABERGER (1999), p. 291-294; FALKENSTEIN (1959), p. 147-182. For the Assyrian akitu, see VON DRIEL (1969), p. 162-167; COHEN (1993), p. 417-427. Earlier scholars were convinced that a "sacred marriage" occurred during the akitu, with FRANKFORT (1948), p. 330 and JAMES (1962), p. 87 arguing that it probably took place at the Esagila; 
cf. PALLIS (1926), p. 197-198; JACOBSEN (1975), p. 65-97; KRAMER (1944), p. 49. For Iddin-Dagan's celebration of a "sacred marriage" in conjunction with the New Year Festival, see BIN 9: 435, lines 170-191, with REISMAN (1973), p. 159-160; for Šulgi, see KLEIN (1981), p. 32. BIDMEAD (2002), p. 25 notes the tendency of recent scholarship to examine the akitu for its "political and sociological significance, doing away with the concepts of hieros gamos, cultic battle, and the motif of the dying-rising god."

7. KLEIN (1992), p. 5.866 defines "sacred marriage" as a "marriage or sexual union between a god and a goddess, in ancient or primitive religions, an act which is usually connected with some form of fertility cult;" also, see BAHRANI (2001), p. 55-56 and 134-140; cf. NOEGEL (2007), p. 21-22 on the issue of Near Eastern influence on Greece, citing LINCOLN (2004), p.658: "Informed by Romantic nationalism and, in part, by the racism associated with it, it [=scholarship of the late nineteenth and early twentieth centuries] understood the 'genius' of Greek civilization as marking the end of antiquity and the start of the 'miracle' that anticipated the Enlightenment by breaking with myth, tradition, and puerile superstition to achieve a critical view of religion."

8. See SEFATI (1998), passim on the hymns accompanying the "sacred marriage" of Dumuzi and Inanna. Cf. PONGRATZ-LEISTEN (2008), p. 66-68, who differentiates between cosmogamy (marriage of heaven and earth), theogamy (divine marriage), and hierogamy (marriage of king and goddess). 9. ODEN (1987), p. 138-147; BIRD (1997), p. 39, with n. 8; SWEET (1994), p. 101; JONES (2003), p. 299.

10. SMITH (2008), p. 93. For "sacred marriages" celebrated in the first millennium BCE, see NISSINEN (2001), p. 99-101, 103-105. For a study of "sacred marriage" in ancient Greece, see AVAGIANNOU (1991), passim but esp.p.19-26; although AVAGIANNOU is right to challenge the uncritical, Fraserian association of "sacred marriage" with fertility (p. xi), I find her own differentiation between marriages involving deities and those involving divine rape rather forced (see esp. her remarks on p. 142-144).

11. BIDMEAD (2002), p. 104; LAPINKIVI (2004), p. 14 and (2008), p. 20-21.

12. COOPER (1993), p. 83 was convinced that actual sex took place between the king and the priestess, a conclusion which he has subsequently rejected; also, see COOPER (2013).

13. HOLLAND (2012) discusses Homer, Il. $14.330-360$ as referring to the "sacred marriage" between Zeus and Hera; cf. HHomAphr. 5.61-190, for the goddess consummating her affair with the Trojan consort Anchises. CLARK (1998), p. 20-22 discusses the re-enactment of the marriage by worshipers at Knossos, as referred to at Diod. Sic. 5.72.4, and the celebration of the institution of marriage, called the Hieros Gamos, in Attica (SEG 26.136.32). The myth of Persephone and Hades might also suggest a hieros gamos at Locri in southern Italy, as SOURVINOU-INWOOD (1978), p. 113114 , argues. For the "sacred marriage" of Persephone at Eleusis, see Strabo 14.1.45, with RUCK (2008), p. 95-98. There is compelling evidence that the Greeks also believed in mortal-divine couplings. The Anthesteria festival in Athens dramatized an annual marriage between the god Dionysos and the mortal basilinna (queen), the wife of the Athenian religious official called the basileus (king); cf. Xen. Hipp. 3.2, and also, see BURKERT (1987), p. 239 and AVAGianNou (1991), p. $177-198$.

14. SAGGS (2000), p. 173.

15. OSHIMA (2007), p. 355 . VAN DER SPEK (2009), p. 110-111 argued that, since we have found no Greek temple in Babylonia, the Greeks may have used the temple of Bēl, now identified with Zeus, as their main cultic space. WRIGHT (2010), p. 58 discusses the identification of Zeus with local Ba'als, possibly since the time of Alexander, as indicated on his famous coins representing the Pheidian Zeus of Olympia.

16. Hdt. 1.181.5-182.1-2; our translation, modified from that of GODLEY (1920). This part of the article is derived from ANAGNOSTOU-LAOUTIDES (2017), p. 84-86.

17. In Urnamma A, Inanna is portrayed as lamenting the king's death. She praises his charms ( $h-$ li-a-ni) and refers to her ğipar as her shrine that "towers up like a mountain." 


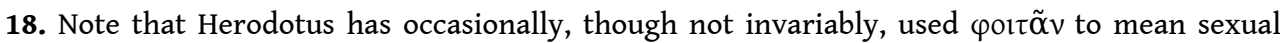

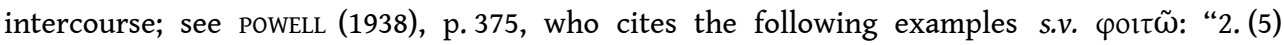

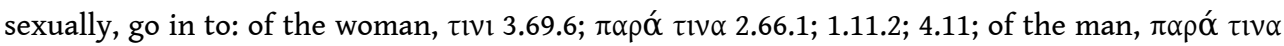
5.70.1."

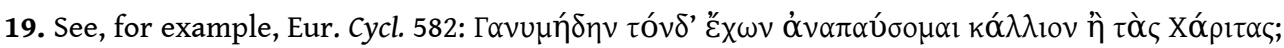

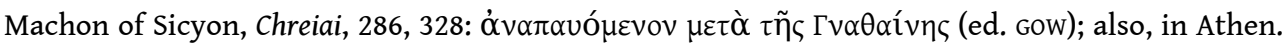

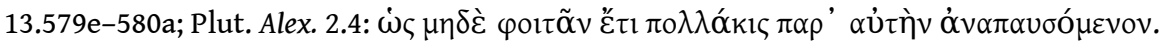

20. NOEGEL (2004), p. 134-135; see also MAUL (2007), p. 368; cf. DURAND (1988), p. 455-482.

21. For incubation as practiced throughout Mesopotamia, see KIM (2011), p. 27-60.

22. SASSON (1984), p. 285; DEJONG ELLIS (1989), p. 136; see also BUTLER (1998), p. 224-227. For incubation among the Jews under ancient Near Eastern influence, see MOORE (1990), p. 78-86; ACKERMAN (1992), p. 194-120. On the Jewish disapproval of incubation, which was perceived as being linked to pagan necromancy, see ScHMIDT (1994), p. 261-263.

23. See Paus. 2.27.3 and Strabo 8.374; for an overview of incubation in the ancient Near East, see KIM (2011), p. 27-58. Cf. HUSSER (1999), p. 20-22, who warns against the conflation of the "therapeutic incubation," popular during the Hellenistic period, and the "oracular" incubation mainly practiced in the ancient Near East in earlier times.

24. Diod. Sic. 1.25.5.

25. DEJONG ELLIS (1989), p. 178-179.

26. E3/1.1.7 CylA; see EDZARD (1997), p. 69-70. Starting with the Akkadian dynasty of Sargon, ancient Near Eastern kings would often place their daughters as priestesses of the god. On this, See HALLO - SIMPSON (1997), p. 175.

27. HUROWITZ (1992), p. 47-48, 153-156. VAN BUREN (1952), p. 293-294, with n. 1, draws our attention to the king's sense of duty and obedience to the expressed wish of gods to have new temples built in their honor. Gudea, for example, was instructed in a dream to build a new and better Eninnu for Ningiršu, the Amorite Samsuiluna (ca. 1792-1712 BCE) was commanded to build a temple by Šamaš, and Waradsin of Larsa (1770-1758 BCE) by Nannar.

28. BUTLER (1998), p. 17-19; see, also, CHAPMAN (2008), p. 41-44.

29. GURNEY (1981), p. 143; cf. BECKMAN (2003), p. 159.

30. Hdt. 1.77 and 188.

31. GADD (1948), p. 58-59 with BÖHL (1939), p. 162 (i 1.170); cf. REINER (1985), p. 1-16, esp. p. 2; BEAULIEU (1989), p. 71-72, 127-132; BEAULIEU (1994), p. 39-40. A liver omen also confirmed the god's "desire," since erešum can actually mean both demand/request and wish/desire. But given that $\bar{e}$ rišu, of the same root, means the bridegroom, the erotic connotations of the word cannot be missed.

32. GARRISON (2012), p. 45.

33. Herodotus' work is full of obscure oracles that require careful interpretation. For oracular allegory in Herodotus, see BENARDETE (1969), p. 7-9; cf. HARTOG (1988), p. 131-133, where oracles -

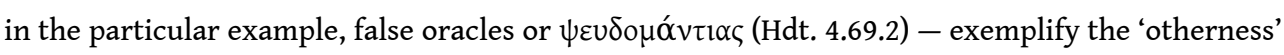
of the Scythians.

34. MIKALSON (2000), p. 55-60 argues that, regardless of whether the oracles were historical or part of contemporary traditions, and not necessarily based on actual events, one has the impression that Herodotus relates them as part of his storytelling in order to teach his audience through the stories and mistakes of those who related the oracles to him. On p.143, while discussing Herodotus' appreciation of human impiety as the source of misinterpreting "the import of oracles, omens, and dreams," he also notes: "Herodotus himself expresses (3.38) and exhibits considerable respect for the 'customs' (vó $\mu \mu \alpha)$ of others, however strange they might seem...but, however open-minded, he cannot silently accept sexual intercourse in religious 
settings...," citing as the first of his examples the "most shameful" custom of the Babylonians recorded at 1.199 .

35. HARRIS (2000), p. 122-157 holds that Herodotus distances himself from popular religion precisely by referring to cases in which erroneous interpretations of oracles precipitated one's downfall. On Herodotean oracles as literary forgeries designed to promote political objectives, see STRUCK (2002), p. 181-183.

36. HUROWITZ (1992), p. 162.

37. MELVILLE (2006), p. 390-391.

38. Granius Licinianus, History of Rome, 28.6 (with Diana). EDDY (1961), p. 141-145 refers to Antiochus marrying Ištar at Babylon. Consider, too, his marriage to Nana at Susa, as recorded in 2 Maccabees 1.13-15 and Polybius 31.9.1.

39. Either Antiochus was a usurper who murdered his brother out of political ambition or, given that there is no evidence clearly associating him with the murder of Seleucus IV, he was the remaining ruler who managed to overcome the conspiracy that brought about the demise of his co-ruler. See Daniel 11:20, with BAHRANI (2002), p. 19 and, contra, SHEA (2005), p. 31-66.

40. PONGRATZ-LEISTEN (2008), p. 66.

41. WIDENGREN (1951), p. 9, 11, 15.

42. SEFATI (1998), p. 224-225.

43. See KRAMER (1944), p. 33-37; FRAYNe (2001), p. 130; WOLKSTEIN - KRAMER (1983), p. 4-5; ANAGNOSTOU-LAOUTIDES (2017), p. 43-46.

44. WESTENHOLZ (2007), p. 36-41; STRONACH (1990), p. 171-174.

45. TURNER (1979), p. 26.

46. BOtTÉRo (1993), passim. DALLEY (1993), p. 1-2 refers to kings trying to recreate a Paradise location. The "sacred marriage" between Nabu and Tasmetu at Calah in Assyria was followed by an animal hunt in a game park, the ambassu. On this, see MATSUSHIMA (1987), p. 139-143; NISSINEN (2001), p. 99; LAPINKIVI (2004), p. 84, n. 289; CAD 1.2.44, s.v. ambassu; SMITH (1958), p. 43-44, with MUNN (2006), p. 136, n. 12.

47. Hdt. 7.26-29.

48. Xen. An. 1.2.7-9. See ANAGNOSTOU-Laoutides (2017), p. 46-48.

49. TUPLIN (1996), p. 109-177 discusses the evidence on Persians gardens and argues that they were invested with an ideology of wealth and prestige. In his opinion, Greek (vegetable) gardens were associated ideologically with sex and education, connections not made in the case of Persian paradeisoi (see esp. p. 75-76, 117 and 129, on Adonis' gardens). The 'gardens' of Adonis were part of the ritual celebration of his affair with Aphrodite, a Greek adaptation of the rites in honor of Ištar and Tammuz, which had become popular in first millennium BCE private religion. However, the Greeks were also aware of Lydian and Persian royal paradeisoi, which they allegedly despised as symptomatic of their owners' luxurious and unmanly character; see BREMMER (2002), p. 112-119. For descriptions of Persian paradeisoi, see Plut. Alcibiades 24.5; Xen. Hell. 4.15.33; An. 1.4.10. In addition, see Xen. Oec. 4.23, where Lysander is surprised to know that Cyrus had been toiling in the garden, an action which was at odds with fine garments and exquisite array of jewelry.

50. Xen. Cyr. 1.3.14; see MUNN (2006), p. 136, with n. 13.

51. Xen. Oec. 4.8-5, 20.

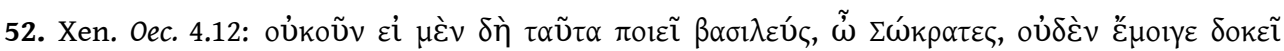

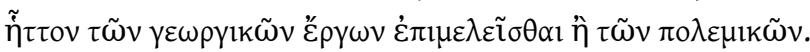

53. Xen. Oec. 4.13; all trans. of Xenophon are by HeINEMANN (1979).

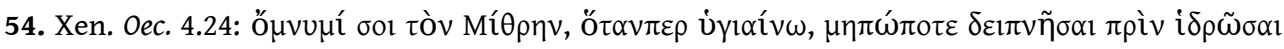

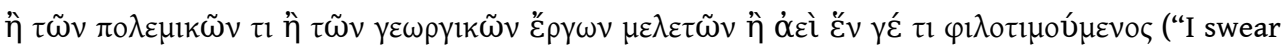


by the Sun-god that I never yet sat down to dinner when in sound health, without first working hard at some task of war or agriculture, or exerting myself somehow").

55. CHARPIN (2013), passim.

56. Xen. Oec. 4.25.

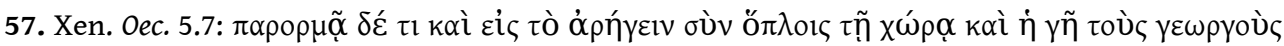

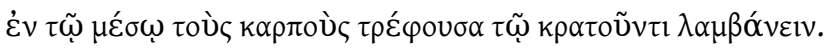

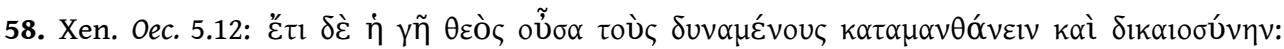

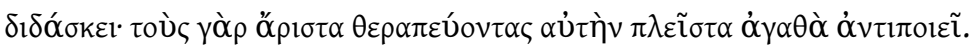

59. Dumuzi is typically addressed in ancient Near Eastern hymns with epithets borrowed from the world of animal husbandry. Thus, he is the shepherd of the people, which is a king's most important task, as is argued by VAN DE MIEROOP (1999), p. 119; LAMBERT (1998), p. 57. HALlo (2010), p. 215 cites hymn B1.13, where Išme-Dagan (ca. 1778-1744 BCE) assumes the role of Dumuzi and is called a "righteous shepherd." In addition, see Hymn DI O in SEFATI (1998), p. 210-217, entitled A Blessing of Abundance for the Bridegroom; cf. his p. 301-311 for DI D1, the Blessing of Dumuzi on the Wedding Day, esp. lines 47-59, where the goddess blesses Dumuzi with shepherdship "over the black-headed people." Dumuzi is compared to a successful farmer and shepherd whose rule will see "orchards and gardens bear juice and fruit under him," as well as "wild sheep and goats multiply in the forests." The hymn concludes with a wish for long life under Dumuzi's rule. Hence, the competition between the farmer and the shepherd over Inanna (SEFATI [1998], p. 324343) may well refer to instances of political rivalry.

60. For text and trans. see ETCSL 1.3.3 (http://etcsl.orinst.ox.ac.uk/section1/tr133.htm); cf. the tale of gardener Ishullanu in GE VI.64-69.

61. See zólyomi (2003), p. 78-79, who cites the Cursing of Agade 2.1.5, lines 172-174; see also Rìm-

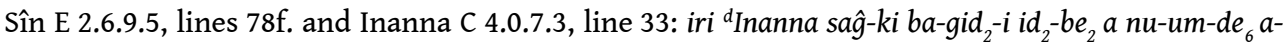
$g r_{3}-b e_{2} \check{s} e n u-m u_{2}-m u_{2}$ I get ("If Inanna frowns upon a city, its river shall carry no water, its arable tracts shall grow no grain").

62. ASSANTE (1998), p. 10 argued that this widespread belief was the unfortunate result of "the patriarchal system scholars have developed and imposed on the study of ancient Mesopotamia;" cf. BUDIN (2006), p. 83.

63. Trans. GODLEY (1920), p. 250-253.

64. Hdt. 1.196 .5 (three final lines of the paragraph, as per GODLEY [1920], p. 248: غं $\pi \varepsilon i ́ \tau \varepsilon ~ \gamma \grave{\alpha} \rho$

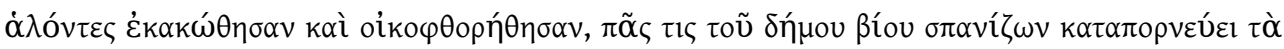

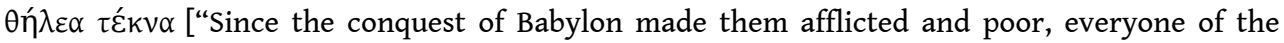
people that lacks a livelihood prostitutes his daughters"]).

65. See COOPER (2013), p. 50-51; MARSMAN (2003), p. 196-198, 498-500; BENKO (2004), p. 39, n. 46, citing, among others, VAN DER TOORN (1989), p. 204, who understands the rite as fulfilling a oncein-a-lifetime vow. On harimtu, see ASSANTE (2003), p. 33. See also the discussion on kezertu in LARSON (2014), p. 223.

66. MACLACHLAN (1992), p. 149.

67. Trans. JONES (1930), p. 227.

68. Trans. JONES (1928), p. 341.

69. For the use of Herodotus by modern colonialists, see SAID (1978), p. 58, 90, 175.

70. On this locus, see GoDLEY (1920), p. 252.

71. Trans. modified from that of YARDLEY (1997), p. 156 after consulting MACLACHLAN (1992), p. 154 and BUDIN (2006), p. 228. See PIRENNE-DELFORGE (1994), p. 345.

72. Trans. YARDLEY (1984), p. 95.

73. BUDIN (2006), p. 86-90, esp. 86-87. PIRENNE-DELFORGE (2007), p. 322.

74. KONSTAN (1987), p. 122-139; cf. MINER (2003), p. 30-34. 
75. RAMSAY (1883), p. 276-277. BUDIN (2003), p. 152-153 also argues that Strabo's differing terms throughout his writing, such as his use of the ostensibly similar pallake, hetaira and hierodoulos, adds to the confusion.

76. ROBERT (1970), p. 406.

77. Text and trans. HAMILTON - FALCONER (1957), p. 263; cf. n. 79 below.

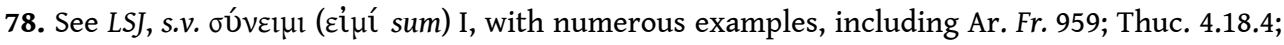
Xen. Oec. 15.12; Pl. Rep. 586a, 586b; Laws, 791 b.

79. Strabo 17.1.46; trans. JONES (1932), p. 125: "to Zeus (Amon) who is held in the highest honour, they dedicate a maiden of greatest beauty and most illustrious family (such maidens are called 'pallades' [virgin-priestesses] or pallacide [harlots] by the Greeks); and she prostitutes herself, and cohabits with whatever men she wishes until the natural cleansing of her body takes place (menstruation); and after her cleansing she is given in marriage to a man; but before she is married, after the time of her prostitution, a rite of mourning is celebrated for her." BUDIN (2008), p. 199 translates the passage as follows: "But for Zeus, whom they [the Thebans] honour most, a beautiful girl maiden of most illustrious family serves as priestess, [girls] whom the Greek called pallades; she serves as a functionary (prophetess) and accompanies whomever/attends whatever [rites] she wishes until the natural cleansing of her body; after her cleansing she is given to a man/husband but before she is given, a rite of morning is celebrated for her after the time of her religious service."

80. PIRENNE-DELFORGE (1994), p. 113-127 and (2007), p. 321.

81. MACLACHLAN (1992), p. 98.

82. FERGUSON (1993), p. 64.

83. BEARD - HENDERSON (1997), p. 196.

84. See JONES (1928), p. 439.

85. For the terms hetaira and porne and their exact meanings in the Greek world, see KURKE (1997), p. 110-115. It seems that hetairai wished to be distinguished from their low-class counterparts, the pornai, by putting less emphasis on receiving money for their services and promoting the idea

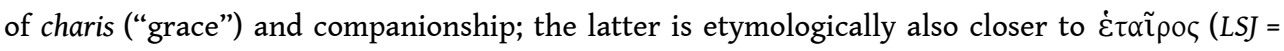
"companion," "friend," "mate").

86. The epithet occurs in the Descent of Inanna, v. 221. On this, see BEAULIEU (2003), p. 112, n. 65.

87. KURKE (1996), p. 52.

88. BUDIN (2006), p. 86. PIRENNE-DELFORGE (1994), esp. p. 113. In addition, see BREITENBERGER (2013), p. 132-135, who agrees that the text does not describe an incident of "sacred prostitution." She points out the role of Peitho in the poem and its association with prostitution in antiquity.

89. See the discussion of this text in MACLACHLAN (1992), p. 160.

90. There is a reference to Inanna's golden girdle in Inanna's Descent to the Underworld (lines 54-55, 121), while the girdle is also very important for the goddess' military aspects; cf. the Agushaya hymn dedicated to Ishtar. For both texts, see FOSTER (1996), p. 1.81-83, 100. Several Sumerian votaries depict male devotees wearing a double rope around their waist and carrying offerings to the goddess. These are probably, according to CRAWFORD (1960), p. 246 and 249, building bricks for the goddess' temple.

91. The hymn mirrors the goddess' ascent to the highest rank of the Assyrian pantheon in the later first millennium BCE; see A ii 12 in GRONEBERG (1997), p. 75; cf. WESTENHOLZ (2007), p. 339.

92. COLLON (2007), p. 104; see also SELZ (2007), p. 277 for the "measuring rope" as one of the insignia that the gods entrusted to the kings for the purposes of according justice.

93. On the famous Games text, see HARRIS (2000), p. 168-169.

94. FEHLING (1989), p. 10 and 247-248; cf. ROLLINGER (2000), p. 76 and (1993), p. 29 and 176, which contain the only references to Babylonian prostitution in the book. 
95. PRITCHETT (1993), p. 235-242. Note that, according to PIRENNE-DELFORGE (2009), Budin inevitably accepts that Herodotus was lying in reporting the custom, thus siding with Pritchett's school of thought.

96. ROLLINGER (2000), passim, discusses the story of the rich Pythios and his son (Hdt. 7.38-40) in light of Hittite rituals and the story of Ascalon and the Scythian invasion of Asia (1.103-106).

97. ROLLINGER (2000), p. 69-70 makes a similar argument for Herodotus' use of the tale of Pythios which Herodotus employs in a way that supports his view of Xerxes as an oriental despot; accordingly, his execution of Pythios' son is not presented as a ritual performed to ensure military victory but as the arbitrary decision of a cruel king.

98. See ASHERI - ANELAMI (1988), p. 222-223, who translate as follows: “ $\grave{E}$ obbligo che ogni donna del paese, una volta durante la vita,postasi nel recinto sacro ad Afrodite, si unisca con uno straniero... Quando una donna si asside in quel posto, non torna più a casa se prima qualche straniero, dopo averle gettato del denaro sulle ginocchia, non si sia a lei congiunto all'interno del tempio." But "postasi" is a reflexive form that the translator understood in connection to $\delta \varepsilon \tilde{\imath}$ and not to the noun үuvaĩk $\alpha$, which is closer to the participle. LEGRAND (1932), p. 195 translates the passage as "toute femme du pays doit, une fois en sa vie, aller prendre place dans un sanctuaire d'Aphrodite et s'unir à un étranger... Lorsqu'une femme a pris place en ce lieu..." Although he avoids reflexive forms, the phrase "aller prendre" implies an understanding of the participle as indicating purpose rather than being adjectival/relative. In Spanish, SCHRADER (2000), p. 256-267 follows this model: "toda mujer del país debe, una vez en su vida, ir a sentarse a un santuario de Afrodita y yacer con un extranjero. ...muchas mujeres toman asiento en el recinto sagrado de Afrodita... Cuándo una mujer ha tomado asiento en el templo..."

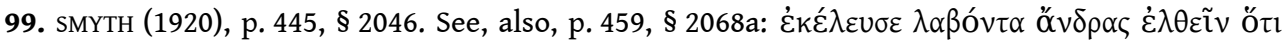

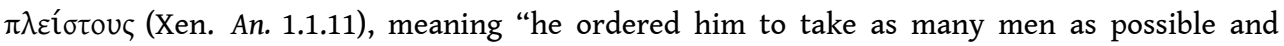
come," with the participle $\lambda \alpha \beta$ óv $\alpha$ being used to express one of the orders.

100. BARTOLOMÉ POU (1989), p. 42 translated the participle as temporal: "estando sentada en el templo de Venus (while sitting)... Después se ha sentado allí," again implying that the custom is obligatory for every woman in the country. His translation is closer to the early German version of BÄHR (1868), p. 149, who wrote: "Eine jede Frau des Landes muß, im Tempel der Aphrodite sitzend, einmal in ihrem Leben sich einem Fremden preisgeben... Wenn sich nämlich eine Frau hier gesetzt hat."

101. See $1.11 .3 ; 1.57 .2 ; 1.67 .5 ; 1.199 .1$ and $3 ; 2.24 .1 ; 2.29 .2 ; 3.6 .2 ; 3.69 .1$ (4 participles); 3.110.1; 5.62.1; 7.2.1; 7.17.2; 7.51.2 and 7.142.3.

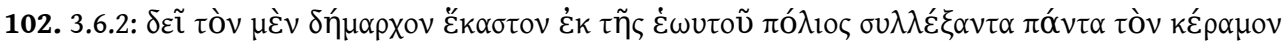

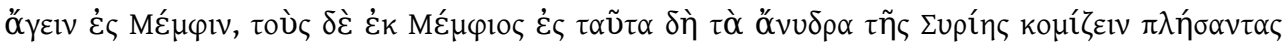

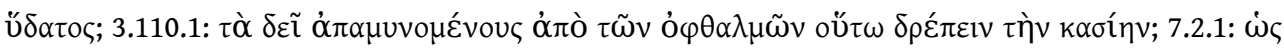

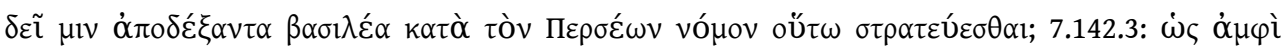

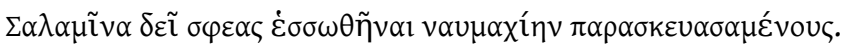

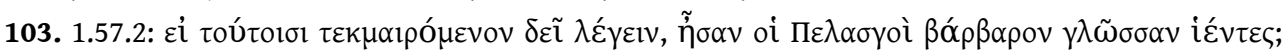

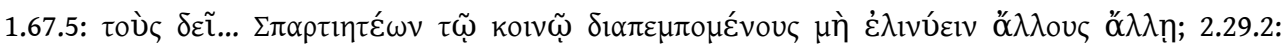

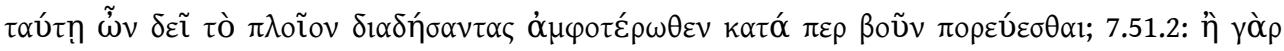

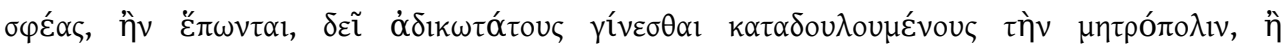

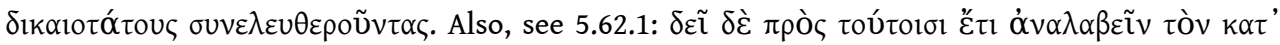

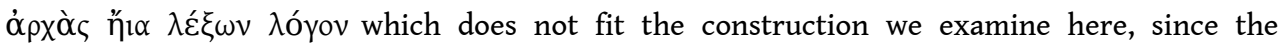

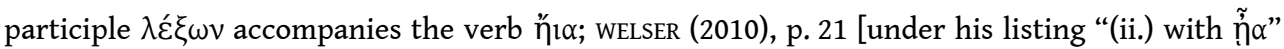
and with his n. 30]; cf. HORNBLOWER (2013), p. 181.

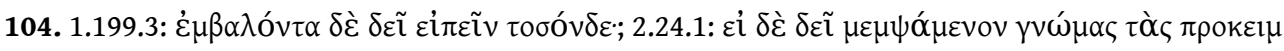

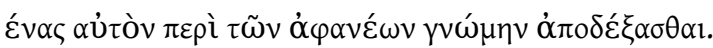

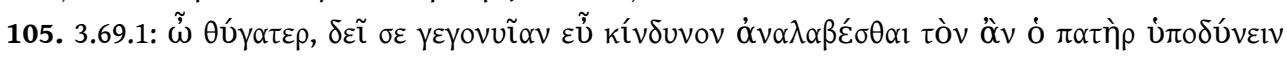

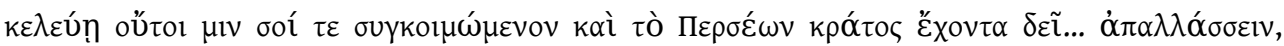




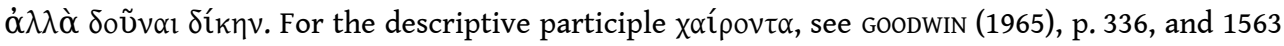
under n. 7.

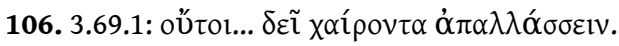

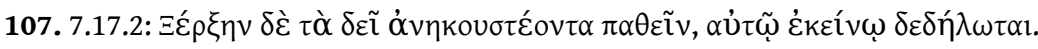

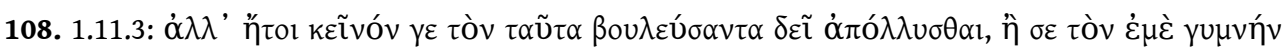

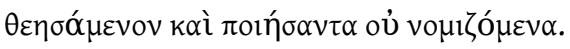

109. GOODWIN (1889), p. 330-331, and 827 (a) notes that the phenomenon is generally observed with plural participles (for example, Xen. Hell. 5.1.19; Cyr. 7.5 and 73), yet he also cites Soph. El.

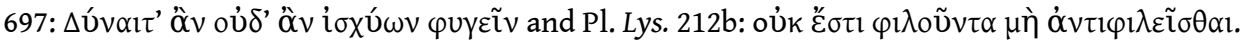

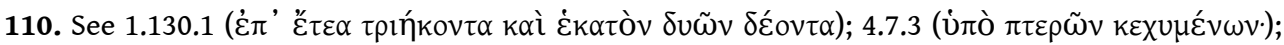

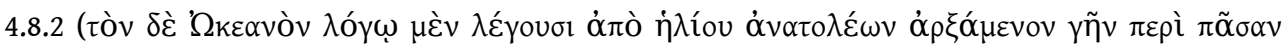

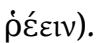

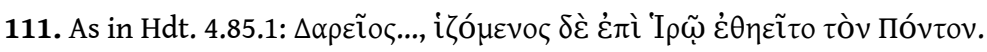

112. Cf. PEELS (2016), p. 207-208 for the debated meaning of óølo̧ used by Herodotus at 1.199.4 ( $\dot{\alpha}$

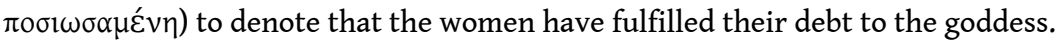

\section{ABSTRACTS}

The article compares Herodotus' representation of "sacred marriage" and "sacred prostitution" with relevant passages in Xenophon, Diodorus, and Strabo. The representation of the "sacred marriage" ritual in ancient near eastern sources points to a venerable custom used to induce divine epiphanies but, also, to a powerful political tool that later rulers used to establish or enhance their legitimacy. Furthermore, Xenophon's appreciation of the divine favor that eastern rulers mustered and the symbolism they used to relate it, indicates that the Greeks neither ignored nor rejected such eastern norms. By taking into account the scholarly arguments that doubt the widespread existence of "sacred prostitution" in antiquity and point to a misreading of Herodotus by later Roman authors, who read his work through the "orientalism" of their day, we argue that Herodotus does not exhibit inherent bias against the Babylonians when reporting the famous custom requiring every Babylonian woman to prostitute herself once in her lifetime. A closer reading of the text suggests that Herodotus was more interested in castigating religious prejudice regardless of the ethnicity of its practitioners.

L'article opère une comparaison entre la représentation du «mariage sacré » et de la « prostitution sacrée » telle que la livre Hérodote et les développements de Xénophon, Diodore et Strabon qui peuvent lui être comparés. La représentation du rituel du « mariage sacré » dans les sources proche-orientales renvoie à une coutume ancienne destinée à induire des épiphanies divines, mais il s'agit également d'un puissant instrument politique que des dynastes plus récents ont utilisé pour établir ou asseoir leur légitimité. De plus, l'appréciation, par Xénophon, de la faveur divine que les souverains orientaux mobilisaient et du symbolisme auquel ils recouraient laisse entendre que les Grecs n'ignoraient ni ne rejetaient de telles coutumes. En tenant compte des interprétations qui doutent de l'existence effective de la "prostitution sacrée " dans l'antiquité et soulignent la mauvaise lecture du texte d'Hérodote par des auteurs romains plus tardifs imbus de l'orientalisme de leur temps, l'article prétend qu'Hérodote ne critique pas les Babyloniens en rapportant la fameuse exigence faite aux femmes de se prostituer une fois dans 
leur vie. Une lecture serrée du texte suggère qu'Hérodote était surtout soucieux de souligner les préjugés religieux, indépendamment de l'origine ethnique de ceux qui accomplissaient les rites.

\section{AUTHORS}

\section{EVA ANAGNOSTOU-LAOUTIDES}

Macquarie University

Eva.Anagnostou-Laoutides@mq.edu.au

\section{MICHAEL B. CHARLES}

Southern Cross University

michael.charles@scu.edu.au 